Rhode Island College

Digital Commons @ RIC

$10-3-2018$

\title{
Efficacy of Alveolar Recruitment Maneuvers in the Adult Obese Patient Undergoing General Anesthesia: A Systematic Review of the Literature
}

Joseph A. Banks

Follow this and additional works at: https://digitalcommons.ric.edu/etd

Part of the Nursing Commons

\section{Recommended Citation}

Banks, Joseph A., "Efficacy of Alveolar Recruitment Maneuvers in the Adult Obese Patient Undergoing General Anesthesia: A Systematic Review of the Literature" (2018). Master's Theses, Dissertations, Graduate Research and Major Papers Overview. 291.

https://digitalcommons.ric.edu/etd/291

This Major Paper is brought to you for free and open access by the Master's Theses, Dissertations, Graduate Research and Major Papers at Digital Commons @ RIC. It has been accepted for inclusion in Master's Theses, Dissertations, Graduate Research and Major Papers Overview by an authorized administrator of Digital Commons @ RIC. For more information, please contact digitalcommons@ric.edu. 


\title{
EFFICACY OF ALVEOLAR RECRUTIMENT MANEUVERS IN THE ADULT OBESE PATIENT UNDERGOING GENERAL ANESTHESIA:
}

A SYSTEMATIC REVIEW OF THE LITERATURE

by

\author{
Joseph A. Banks
}

A Major Paper Submitted in Partial Fulfillment of the Requirements for the Degree of

Master of Science in Nursing

in

The School of Nursing

Rhode Island College

2018 



\begin{abstract}
There are many pathophysiologic health effects associated with obesity, and the effects on normal respiratory physiology can be profound. The presence of increased adipose tissue can limit a patient’s functional residual capacity, reduce end expiratory lung volumes, and increase small airway closure. When exposed to general anesthesia with mechanical ventilation these physiologic changes can increase atelectasis development and increase the likelihood of ventilation-perfusion mismatching. Alveolar recruitment maneuvers are brief applications of positive airway pressure that are employed to recruit alveoli that have already collapsed and prevent new atelectasis formation. The purpose of this systematic review was to determine if the use of alveolar recruitment maneuvers are a safe and effective treatment strategy for managing the adult obese patient requiring general anesthesia with mechanical ventilation. The theoretical framework that guided this systematic review was the Preferred Reporting Items for Systematic Reviews and Meta-Analyses (PRISMA) checklist. Randomized control trials that utilized alveolar recruitment maneuvers in adult obese patients were reviewed and appraised for inclusion in this systematic review. It was determined that alveolar recruitment maneuvers are a safe and effective strategy for minimizing atelectasis development in the adult obese patient undergoing general anesthesia. Alveolar recruitment maneuvers were associated with an improved intraoperative oxygenation, a decreased alveolar-arterial oxygen concentration gradient, and improved lung compliance. Furthermore, alveolar recruitment maneuver use demonstrated a decrease in atelectasis development measured via computed tomography and radiograph imaging. Application of these maneuvers in the obese patient during the perioperative period can improve ventilation-perfusion matching and decrease respiratory complications associated with atelectasis development.
\end{abstract}





\section{Table of Contents}

Background/Statement of the Problem .................................................................. 1

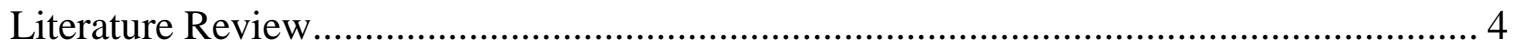

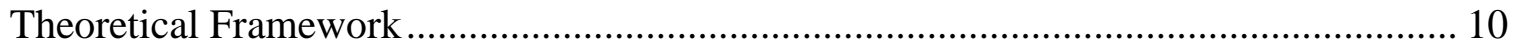

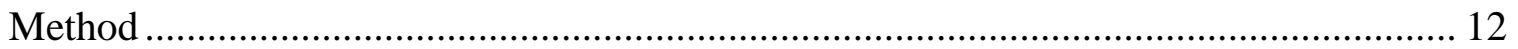

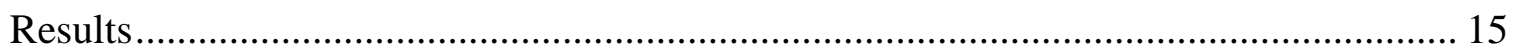

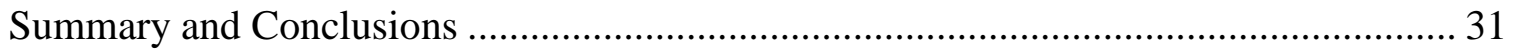

Recommendations and Implications for Advanced Nursing Practice ............................. 34

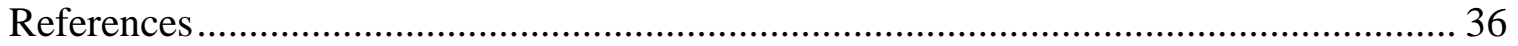

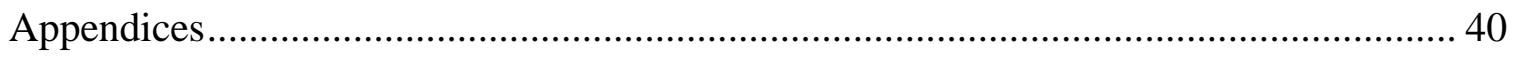


Efficacy of Alveolar Recruitment Maneuvers in the Adult Obese Patient Undergoing General Anesthesia: A Systematic Review of the Literature

\section{Background/Statement of the Problem}

The incidence of obesity is rising in the United States (National Institute of Health [NIH], 2017). It is imperative that practitioners encourage healthy lifestyle choices and educate patients about the negative health consequences of obesity in an attempt to limit this trend. Simultaneously, healthcare providers need to investigate the best treatment modalities for caring for this growing population by incorporating knowledge of the specific physiology and associated sequelae that effect patients with obesity into their plan of care.

Obesity has many harmful effects on normal physiology, and there are many pathophysiologic conditions that are a direct result. Obesity is linked to cardiac, pulmonary, neurological, endocrine, musculoskeletal, and gastrointestinal disease (Talab et al., 2009). Some of these conditions include coronary artery disease, deep vein thrombosis, pulmonary embolism, cerebral vascular accidents, obstructive sleep apnea, inadequate pulmonary reserve, diabetes mellitus, liver dysfunction, arthritis, and degenerative joint disease (Talab et al.).

There are many complications associated with providing anesthesia for the obese patient. There is often difficulty in locating veins utilized for delivering intravenous medications or recognizing anatomical landmarks as reference points (American Society of Anesthesiology [ASA], 2016). There is often confusion in determining the correct dose of medications; with some medications being dosed on ideal body weight, while others are dosed on actual body weight (ASA). Many anesthetic drugs are also lipophilic, which 
can slow the metabolism of medications and lead to a delay in the emergence from anesthesia in the obese patient. There is the potential for serious difficulty in managing the airway and respiratory system of the obese patient, including difficulty in preventing airway obstruction, and risk of traumatic endotracheal tube placement due to enlarged neck circumference or increased soft tissue that can easily obstruct the patient's airway (ASA).

Preventing perioperative pulmonary complications such as atelectasis in the anesthetized surgical patient is a primary responsibility of the anesthesia provider. Atelectasis affects approximately $90 \%$ of patients under general anesthesia (Nagelhout \& Plaus, 2014). This collapse of pulmonary tissue prevents the transfer of oxygen and carbon dioxide, and can lead to the development of hypoxia, hypoxemia, hypercarbia, and respiratory distress. Special consideration must be given during the perioperative planning for the obese patient in order to limit postoperative respiratory complications. Limiting the development of perioperative atelectasis in the anesthetized surgical patient helps to ensure ventilation-perfusion matching allowing patients to adequately perfuse the tissues of the body with the oxygen required for metabolic function and the sustainment of life.

It is beneficial for practitioners providing anesthesia to the obese patient to have a clear understanding of the care they can deliver during induction, maintenance, and emergence of anesthesia that will help limit the development of atelectasis. The impact of the changes associated with obesity on the respiratory system needs to be a forethought to limit respiratory compromise in the perioperative period and improve the likelihood of a meaningful recovery. 
The purpose of this study was to complete a systematic review related to the impact of alveolar recruitment maneuvers on the prevention of perioperative atelectasis and respiratory complications in the adult obese patient undergoing general anesthesia. Implications for limiting the development atelectasis will be identified. Complications of atelectasis include respiratory distress, hypoxia, and anoxic injury, which can negatively impact the health of the patient undergoing general anesthesia without prompt medical intervention.

Next, a review of the literature will be presented. 


\section{Literature Review}

\section{Epidemiology of Obesity}

The World Health Organization (WHO, 2017) identifies obesity as an abnormal or disproportionate fat accumulation that may negatively impact health. A patient with a Body Mass Index (BMI) of $30-34.9 \mathrm{~kg} / \mathrm{m}^{2}$ is considered obese (class I). Body Mass Index classifications include: underweight; normal; overweight; obesity (class I); obesity (class II); morbid obesity (class III); super obesity; and super-super obesity (Barash et al., 2013).

- $\quad<18.5$ - Underweight

- $18.5-24.9$ - Normal

- 25 - 29.9 - Overweight

- 30 - 34.9 - Obesity (class I)

- 35 - 39.9 - Obesity (class II)

- $\geq 40$ - Morbid Obesity (class III)

- $\geq 50$ - Super Obesity

- $\geq 60$ - Super-Super Obesity

(Barash et al., 2013)

To determine BMI, weight in kilograms is divided by height in meters squared $\left(\mathrm{kg} / \mathrm{m}^{2}\right)(\mathrm{WHO})$. According to the Centers for Disease Control and Prevention [CDC], 2016) more than one third of adults in the United States and approximately $17 \%$ of children and adolescents are considered obese. Globally, the number of adults and children that are overweight or obese is a staggering 1.9 billion and 40 million respectively (WHO, 2017). As of 2008, the medical care cost of obesity in the United States was estimated to be 147 billion dollars annually (CDC).

People who are obese are at an increased risk for many medical and psychological conditions. Obese people have a higher incidence of hypertension, coronary artery disease, type 2 diabetes, obstructive sleep apnea, osteoarthritis, pain, anxiety, and 
depression (CDC, 2016). The medical consequences of obesity directly affect the quality and quantity of a person's life. Nationally, obesity is considered the second leading cause of preventable death, with approximately 300,000 deaths per year (Goode et al., 2016).

\section{Pulmonary Sequela of Obesity}

Obesity has significant negative impacts on respiratory physiology. The presence of adipose tissue causes a reduction in functional residual capacity (FRC), limiting expiratory flow and increasing the risk of airway closure (Salome, King, \& Berend, 2009). Functional residual capacity is the volume of gas remaining in the lungs following passive expiration, serving as an oxygen reserve (Barash et al., 2013). Obesity causes a reduction in lung compliance, leading to the further development of preexisting atelectasis (Salome et al.). Obesity increases oxygen consumption and carbon dioxide production and can weaken the respiratory muscles utilized for the work of breathing (Salome et al.). Due to the consequences of obesity on respiratory physiology, the obese patient is likely to have significant oxygen desaturation, developing twice as fast as a patient of normal weight (Jense, Dubin, Sliverstein, \& O’Leary, 1991). This drastically reduces the time a patient can endure hypoxia before the development of permanent anoxic injury.

Obese patients have a greater risk of atelectasis development than non-obese patients and preventing atelectasis is especially important for the obese patient to limit further respiratory compromise (Talab et al., 2009). Obese patients have impaired pulmonary function during anesthesia due to the formation of atelectasis and are more prone to the development of atelectatic tissue compared to patients of normal BMI 
(Reinius et al., 2009). Tidal volumes $\left(\mathrm{V}_{\mathrm{T}}\right)$ are often reduced with obesity, leading to a shallow rapid breathing pattern and the development of atelectasis from under ventilated alveoli (Salome et al., 2009).

Adipose tissue of the abdomen and thoracic cavity lead to a reduction in lung volumes and impairs the stability of the airways, leading to the collapse of alveoli (Imber et al., 2016). Obesity causes an increase in chest wall resistance, decreased FRC and forced vital capacity (VC), all of which increase the incidence of postoperative atelectasis (Thompson et al., 2011). Obesity predisposes patients to lung collapse and hypoxemia during the induction of anesthesia due to the patients' decreased lung volumes (Futier et al., 2011).

Perioperative respiratory complications can have a significant impact on the meaningful recovery of patients. Due to their body habitus obese patients are at increased risk for respiratory complications. Reduced FRC results in lung volumes below the closing capacity leading to small airway closure, ventilation-perfusion mismatch, rightto-left shunting, and arterial hypoxemia (Barash et al., 2013). Additionally, these respiratory complications can lead to increased atelectasis formation, respiratory distress, reintubation with mechanical ventilation, and respiratory failure without medical treatment (Domi \& Laho, 2012). Pulmonary conditions associated with obesity include atelectasis, hypoventilation, obstructive sleep apnea, and respiratory distress (Dambaugh, 2016). Obesity is associated with an increased risk of developing community acquired pneumonia and mortality of the obese patient is directly proportional to their BMI (Kahlon et al., 2013). 
Postoperative morbidity is increased in obese patients due to a higher risk of sedation-induced respiratory depression (Barash et al., 2013). This is especially important in the post anesthesia care unit (PACU) where the anesthesia provider is no longer at the bedside directly monitoring for signs and symptoms of respiratory compromise. Obesity in conjunction with pre-existing diseases such as obstructive sleep apnea or metabolic syndrome significantly increases the risk of morbidity and mortality in the obese patient undergoing anesthesia (Barash et al.).

\section{Alveolar Recruitment Maneuvers}

According to Talab et al. (2009), as much as $15 \%$ of the lung can develop atelectasis during the delivery of anesthesia, with the basal region most prone to atelectatic tissue development. Several alveolar recruitment maneuvers have been utilized to reduce the degree of intraoperative atelectasis development. Alveolar recruitment maneuvers are brief applications of continuous positive airway pressure used to open alveoli that have collapsed (Siegel \& Hyzy, 2017). There is no consensus on the best way to provide these maneuvers, the preferred frequency of these maneuvers, or duration of their usage (Siegel \& Hyzy).

An incremental increase in $\mathrm{V}_{\mathrm{T}}$ from $13 \mathrm{ml} / \mathrm{kg}$ to $22 \mathrm{ml} / \mathrm{kg}$, a stepwise increase in positive end expiratory pressure (PEEP), or sustained lung inflation of up to $55 \mathrm{~cm} \mathrm{H}_{2} \mathrm{O}$ for 10 seconds followed by application of PEEP are some of the alveolar recruitment maneuvers in practice (Miller, 2015). Applied Positive End Expiratory Pressure or PEEP is the pressure that remains in the alveoli at the end of expiration (Sagana \& Hyzy, 2017). 
PEEP can be therapeutically applied to patients on mechanical ventilation to increase oxygenation by preventing alveolar collapse (Sagana \& Hyzy).

Sustained lung inflation is an alveolar recruitment maneuver that involves continuous positive pressure during inspiration via the anesthesia breathing circuit (Gertler, 2017). The sustained pressure is accomplished by increasing the pressure via the adjustable pressure limiting (APL) valve while squeezing and holding the anesthesia breathing bag for 8 - 10 seconds, while monitoring the inspiratory pressure gauge (Gertler). Incremental increase in $\mathrm{V}_{\mathrm{T}}$ can be used as an alveolar recruitment maneuver (ARM). This ARM provides a supra-physiologic tidal volume to the patient, with the objective of inflating dependent areas of the lungs, which are the most prone to alveolar collapse (Miller et al., 2015).

Determining the best treatment modality for intraoperative management of the anesthetized obese patient is essential in limiting the development of atelectasis and postoperative respiratory compromise. Proponents for the utilization of alveolar recruitment maneuvers in obese patients have demonstrated a decrease in lung atelectasis compared to control groups measured by computerized tomography (CT) scan (Talab et al., 2009). Patients treated with alveolar recruitment maneuvers have also experienced less postoperative respiratory complications and had shorter admissions in the PACU (Talab et al.). The aim of ARM with the application of PEEP is to prevent small airway closure, improve ventilation-perfusion matching and oxygenation (Barash et al., 2013). According to Reinus et al. (2009), the application of an alveolar recruitment maneuver followed by the utilization of PEEP increased the $\mathrm{Pao}_{2} / \mathrm{Fio}_{2}$ ratio for approximately 40 minutes. This demonstrates that patients treated with alveolar recruitment maneuvers 
benefit from having a decrease in atelectatic tissue and more functional alveoli available to participate in gas exchange needed for metabolic activity and the sustainment of life.

Comparing the various methods that have been studied provides further evidence for the continued application of alveolar recruitment maneuvers in the perioperative period. It is necessary to perform a systematic review related to the use of alveolar recruitment maneuvers in the adult obese patient undergoing general anesthesia to adequately ascertain if these maneuvers benefit the patient.

Next, the theoretical framework utilized to guide this systematic review will be presented. 


\section{Theoretical Framework}

The theoretical framework that guided this systematic review was the Preferred Reporting Items for Systematic Reviews and Meta-Analyses (PRISMA). The PRISMA Statement (Appendix A) consists of a 27-item checklist and four-phase flow diagram (Liberati et al., 2009). These items are deemed necessary for transparent reporting of systematic reviews. The PRISMA checklist is divided into seven sections including title, abstract, introduction, methods, results, discussion, and funding (Liberati et al.). Under each section are the necessary guidelines for developing an accurate and complete systematic review.

The four-phase flow diagram (Figure 1), developed by PRISMA, provides a graphic representation for article identification, screening, eligibility determination, and the final included studies (Liberati et al., 2009). Identification provides information on the number of records discovered through database searching as well as records identified from other sources (Liberati et al.).

Initial screening was completed on the retrieved data for potential eligibility. Duplicate articles identified in the initial search were then removed. Full-text articles were then evaluated for inclusion in this systematic review. Those articles that met the expressed eligibility criteria were included in this systematic review. Further data extraction was completed on the included studies and the results are presented in this systematic review. 
PRISMA 2009 Flow Diagram

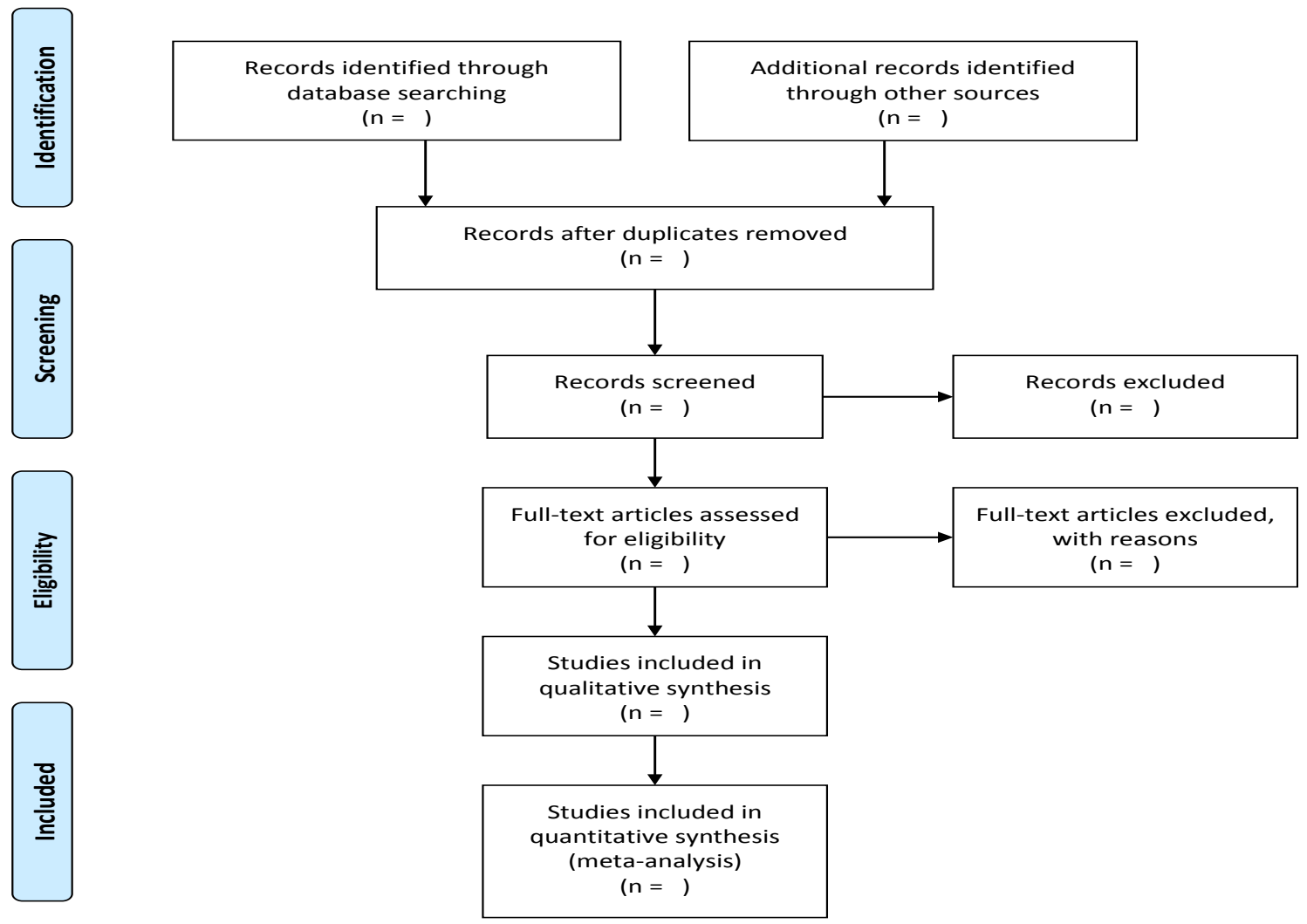

Figure 1. Four-phase flow diagram for preferred reporting items for systematic reviews and meta-analyses (Liberati et al., 2009).

Next, the method section for this systematic review will be discussed. 


\section{Method}

The purpose of this paper was to complete a systematic review related to the impact of alveolar recruitment maneuvers on the prevention of atelectasis and respiratory complications in the adult obese patient undergoing general anesthesia in the perioperative period. Implications for limiting atelectasis which can lead to the development of ventilation-perfusion mismatching, hypoxemia, respiratory distress, and anoxic injury were identified. Randomized control trials involving the use of alveolar recruitment strategies in the adult obese patient were reviewed and screened for inclusion.

Research examining the use of alveolar recruitment maneuvers was sought through database inquiries utilizing CINHAL, Pubmed, and Medline. Search terms implemented included obese or obesity, alveolar recruitment maneuvers, and general anesthesia or anesthesia. The search terms are documented so article identification and retrieval can be duplicated. Additional literature was sought utilizing Google Scholar and internet search engines.

Inclusion criteria for this systematic review was limited to the utilization of alveolar recruitment maneuvers in the adult obese patient with a BMI $\geq 30 \mathrm{~kg} / \mathrm{m}^{2}$ undergoing general anesthesia, requiring intubation with positive pressure ventilation. All surgical procedures utilizing these maneuvers was considered for inclusion. Research studies considered for inclusion in this systematic review were limited to randomized control trials. Research was limited to patients who receive alveolar recruitment maneuvers as part of their anesthetic management during their surgical procedure. Complications considered for examination included the emergent use of supplemental 
oxygen postoperatively, reintubation with mechanical ventilation, hypoxia, hypercarbia, respiratory distress, or the development of postoperative pneumonia.

The continued use of supplemental oxygen in the post anesthesia care unit, utilization of non-invasive ventilation following anesthesia, and patients requiring reintubation with mechanical ventilation following extubation are some of the difficulties associated with postoperative atelectasis development. Objective data of intraoperative atelectasis may be measured by CT imaging scan pre- and post-operatively, arterial blood gas analysis in the perioperative period, adventitious breath sounds, and signs of respiratory distress. Subjective data includes patient complaints of shortness of breath, difficulty breathing, and perceived ability or inability to complete activities of daily living.

Studies including non-obese patients under the age of eighteen years old were excluded. Studies where patients had a diagnosis of Acute Respiratory Distress Syndrome (ARDS), or chronic obstructive pulmonary disease (COPD) were excluded from this systematic review so the efficacy of alveolar recruitment maneuvers could be evaluated in the context of obesity alone.

For each individual study, data collection tables were developed to adequately appraise the randomized control trials. The study specific data (Appendix B) considered for collection includes: aim, design, site, sample, method, and outcomes of interest. Outcome specific data (Appendix C) includes alveolar recruitment maneuvers utilized, control group treatment, outcomes, and any complications associated with the development of atelectasis or from alveolar recruitment maneuver utilization. 
Following data extraction, randomized control trials selected for inclusion in this systematic review were appraised applying the Critical Appraisal Skills Programme (CASP) checklist (Appendix D). The CASP checklist includes 11 questions for evaluating randomized controlled trials. The questions help guide whether the included randomized control trials correlate with the subject matter of the systematic review. The CASP checklist determines the validity of the results, conception of the results, and whether the results can be applied to a specific population (CASP, 2017).

A cross study analysis table (Appendix E) was then created to compare the randomized control trials included in this systematic review. Information considered for collection included the protocol utilized for each study and the major study outcomes. In compiling the data from individual randomized control studies into one cross study analysis table, evidence for the continued use of alveolar recruitment maneuvers and which alveolar recruitment maneuver was of most benefit to the obese patient may be inferred.

It was hypothesized that the data will demonstrate that use of alveolar recruitment maneuvers in the adult obese patient undergoing general anesthesia is a beneficial practice, with little deleterious effect to the patient and that alveolar recruitment maneuvers directly reduce the incidence of respiratory complications during the perioperative period.

Next, the results section will be discussed. 


\section{Results}

The completed four-phase flow diagram (Figure 2) on the following page shows a graphic representation of records identified, screened, and included in this systematic review. Final search terms included alveolar recruitment maneuvers, obesity, and anesthesia. Records considered for inclusion were limited to randomized control trials, with adult subjects. Studies involving respiratory or cardiac comorbidities were excluded so the efficacy of alveolar recruitment maneuvers could be evaluated in the strict context of the adult obese patient. 


\section{PRISMA 2009 Flow Diagram}
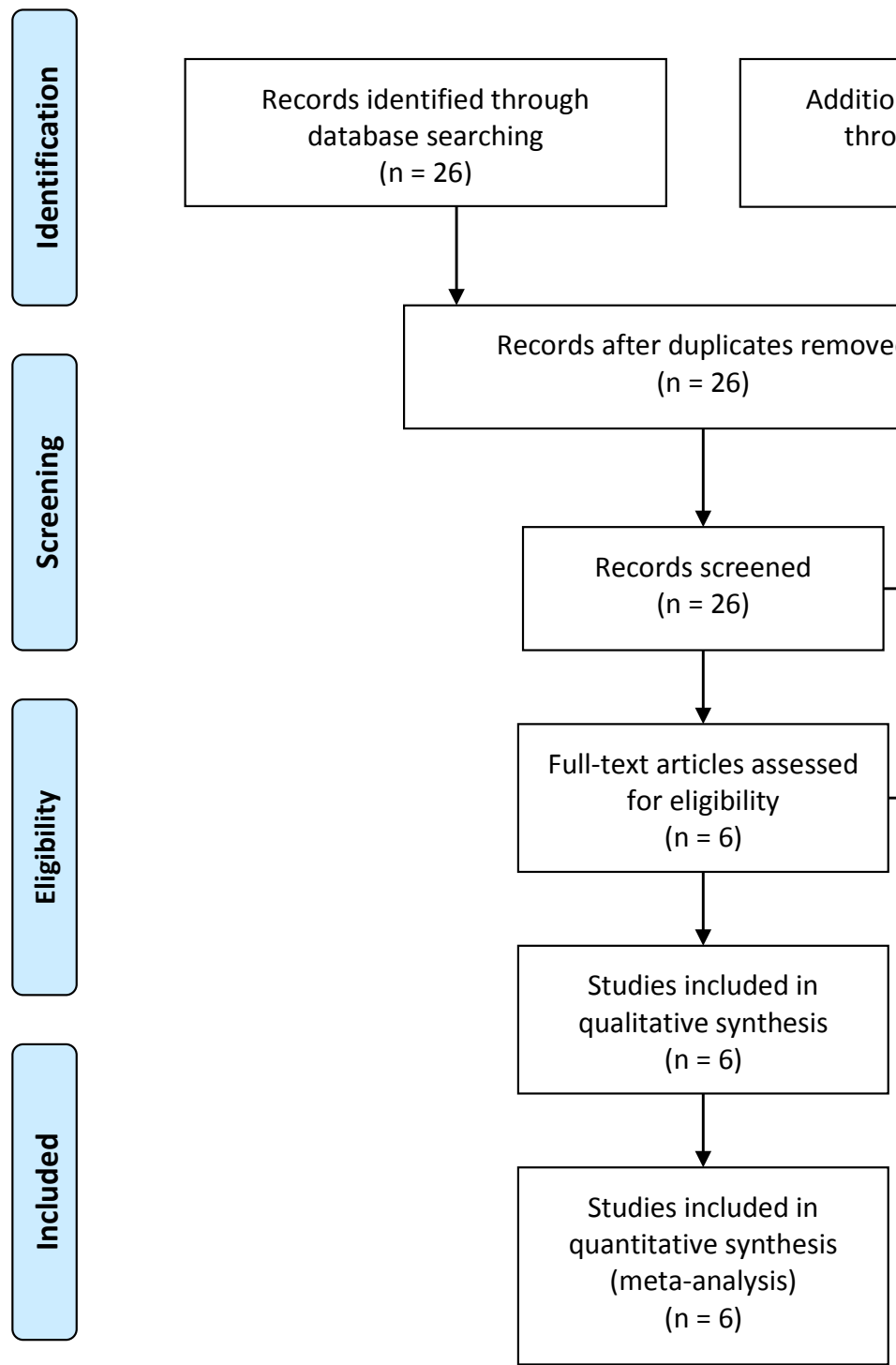

Figure 2. Completed four-phase flow diagram showing article identification, screening, eligibility, and inclusion (Liberati et al., 2009). 
Each study evaluated for this systematic review includes a narrative of the findings associated with the utilization of alveolar recruitment maneuvers in the adult obese patient; major findings will be evaluated and presented. Study specific data collection tables (Appendix B) and outcome specific data collection tables (Appendix C) are included for reference. Critical appraisal data collection tables (Appendix D) are also included to evaluate the integrity of the scientific design of the reviewed studies. Finally, a cross-study analysis table (Appendix E) was developed to compare the protocol and outcomes across the individual RCTs.

\section{Individual Study Analysis}

The single center randomized control trial completed by Chalhoub et al., (Appendix B, Table B-1), evaluated the efficacy of an alveolar recruitment maneuver (ARM) with the adjunct of PEEP in comparison to the use of PEEP alone. The ARM group consisted of a positive inspiratory pressure of $40 \mathrm{~cm} \mathrm{H}_{2} \mathrm{O}$ held for 15 seconds, followed by PEEP of $8 \mathrm{~cm} \mathrm{H}_{2} \mathrm{O}$. The control group consisted of the use of $8 \mathrm{~cm} \mathrm{H}_{2} \mathrm{O}$ of PEEP alone. This RCT included 52 adult obese patients with a BMI $>40 \mathrm{~kg} / \mathrm{m}^{2}$, divided into two equal groups. All patients that participated in this study underwent open bariatric surgery and required endotracheal intubation with positive pressure ventilation. Arterial blood gas analysis was completed prior to the application of the ARM and/or PEEP, again five minutes after the application of the ARM and/or PEEP, and before abdominal closure.

Outcomes of this study (Appendix C, Table C-1) demonstrated that individuals in the experimental group had an increased arterial partial pressure of oxygen $\left(\mathrm{PaO}_{2}\right)$, 
improved arterial hemoglobin oxygen saturation $\left(\mathrm{SaO}_{2}\right)$, and decreased alveolar-arterial oxygen pressure gradient $\left(\mathrm{A}-\mathrm{a} \mathrm{DO}_{2}\right)$. These improvements were seen over the PEEP alone group as soon as five minutes after the application of the ARM. Improvements over the PEEP alone group were sustained at all measured time intervals. Improved $\mathrm{SaO}_{2}$ was demonstrated in the ARM group $(\mathrm{P}=0.035)$. The ARM group also had an increased $\mathrm{PaO}_{2}$ and decreased $\mathrm{A}-\mathrm{a} \mathrm{DO}_{2}(\mathrm{P}=0.001)$. These findings indicate that those obese patients treated with the ARM and PEEP had more efficient gas exchange and improvement in intraoperative arterial oxygenation compared to the PEEP alone group. This improvement occurred immediately after the application of the ARM and was sustained throughout the entire anesthetic and surgical procedure. There was no hemodynamic instability or pulmonary barotraumas related to the application of the ARM with PEEP or PEEP alone. (Chalhoub et al., 2007).

When evaluating the study utilizing CASP (Appendix D, Table D-1), the two groups were comparable regarding age, sex, BMI, and surgical time (Chalhoub et al., 2007). Patients were randomized to one of two groups by opening sealed envelopes. All underwent open gastric bypass performed by the same surgical team. All patients were mechanically ventilated with a Vt of $10 \mathrm{~mL} / \mathrm{kg}$ of ideal body weight, respiratory rate was adjusted to maintain end-tidal carbon dioxide level between 30 - $35 \mathrm{mmHg}$, an inspiratory-expiratory time ratio of 0.4 , and an admixture of oxygen and nitrous oxide to have a fraction of inspired oxygen concentration of $40 \%$ (Chalhoub).

All patients were accounted for at the end of the study. Treatment effect was not specifically mentioned in this study. The results of the study can be applied to adult obese patients undergoing general anesthesia. There were no harmful effects from the 
utilization of ARM reported. The authors concluded that the effect of the ARM accelerated and magnified the therapeutic application of PEEP. These improvements occurred in as little as five minutes and lasted as long as positive pressure ventilation of the lungs continued.

The prospective double-blind randomized control study completed by Talab et al. (2009) (Appendix B, Table B-2) evaluated the use of an ARM with the application of PEEP at both 5 and $10 \mathrm{~cm} \mathrm{H}_{2} \mathrm{O}$ in comparison to the utilization of an ARM with zero end expiratory pressure (ZEEP). The ARM consisted of an inspiratory pressure equal to 40 $\mathrm{cm} \mathrm{H}_{2} \mathrm{O}$ maintained for 7-8 seconds. This RCT consisted of 66 adult obese patients with a BMI of $30-50 \mathrm{~kg} / \mathrm{m}^{2}$, divided into three equal groups of 22 participants.

All patients underwent laparoscopic bariatric surgery and required general anesthesia with intubation and mechanical ventilation. Outcomes measures included length of stay in the post anesthesia care unit (PACU), the need for $100 \% \mathrm{O}_{2}$ in the PACU, A-a $\mathrm{DO}_{2}$, degree of atelectasis measured via CT scan, and rate of pulmonary complications, which included oxygen desaturation, chest infection, and bronchospasm.

Arterial blood gas analysis was measured prior to anesthesia induction and before discharge from the PACU. Computed tomography imaging was completed on admission and immediately following discharge from the PACU. Post anesthesia care unit length of stay was recorded in minutes and the rate of pulmonary complications and need for rescue with $100 \% \mathrm{O}_{2}$ was also recorded in the PACU.

The results of this study (Appendix C, Table C-2) demonstrated the greatest reduction in $\mathrm{A}-\mathrm{a} \mathrm{DO}_{2}$ in the ARM with $10 \mathrm{~cm} \mathrm{H}_{2} \mathrm{O}$ PEEP compared to both the ARM 
with $5 \mathrm{~cm} \mathrm{H}_{2} \mathrm{O}$ PEEP and the ARM with ZEEP groups $(\mathrm{P}<0.05)$. This finding indicates that patients in the ARM with $10 \mathrm{~cm} \mathrm{H}_{2} \mathrm{O}$ PEEP had improved alveolar function and more efficient gas exchange. CT imaging proved that there was a decreased amount of atelectatic tissue in the $\mathrm{ARM}$ with $10 \mathrm{~cm} \mathrm{H} \mathrm{H}_{2} \mathrm{O}$ group compared to both other groups $(\mathrm{P}<$ 0.05). This further demonstrates that the use of ARM in conjunction with PEEP decreases the amount of atelectasis, improving ventilation-perfusion matching. Additionally, the ARM with10 $\mathrm{cm} \mathrm{H}_{2} \mathrm{O}$ group had a decreased length of stay in the PACU, fewer incidence of the need for rescue with $100 \% \mathrm{O}_{2}$, and no pulmonary complications compared to the other groups $(\mathrm{P}<0.05)$.

When evaluating the study using CASP (Appendix D, Table D-2) the three groups were comparable in age, sex, and BMI (Talab et al., 2009). The three groups were randomized, and the study was double-blind. Researchers were unaware of which treatment group participants were assigned. Apart from the experimental intervention, all participants were treated equally. Mechanical ventilation was completed in all groups with volume-controlled ventilation with a mixture of 50\% oxygen and air, and a Vt of 8$10 \mathrm{~mL} / \mathrm{kg}$ based on lean body weight, respiratory rate was adjusted to maintain an endtidal carbon dioxide partial pressure between 32 - 36 mmHg (Talab et., 2009). Pharmacological induction of anesthesia was conducted the same way for all participants.

All patients were accounted for at the end of the study. Treatment effect was not specifically mentioned in the study. The results can be applied to the context of adult obese patients undergoing general anesthesia with mechanical ventilation. Researchers concluded that ARM followed by the addition of $10 \mathrm{~cm} \mathrm{H}_{2} \mathrm{O}$ PEEP was accompanied by better intraoperative and postoperative oxygenation, with decreased atelectasis 
development measured via CT scan (Talab). These results are of clinical importance and demonstrate a synergistic benefit of utilizing an ARM in conjunction with PEEP in the adult obese patient undergoing general anesthesia with mechanical ventilation.

The prospective randomized control study completed by Futier et al. (2011) (Appendix B, Table B-3) evaluated the effectiveness of utilizing alveolar recruitment maneuvers following pre-oxygenation with noninvasive positive pressure ventilation (NPPV) prior to the induction of anesthesia. All patients underwent general anesthesia for laparoscopic sleeve gastrectomy and the study included 66 adult obese patients with a BMI of $46 \pm 6 \mathrm{~kg} / \mathrm{m}^{2}$.

Participants were split into three equal groups. Group 1 received conventional preoxygenation with $100 \% \mathrm{O}_{2}$ via nonrebreather mask for 5 minutes prior to the induction of anesthesia. Group 2 received 5 minutes NPPV alone, while group 3 received 5 minutes of NPPV and the application of an ARM that consisted of an inspiratory pressure $40 \mathrm{~cm}$ $\mathrm{H}_{2} \mathrm{O}$ held for 40 seconds following tracheal intubation.

The results of the study (Appendix C, Table C-3) demonstrated an improved perioperative $\mathrm{PaO}_{2}$ in the NPPV with ARM group compared to the conventional preoxygenation group and the NPPV alone group $(\mathrm{P}<0.0001)$. The increase in $\mathrm{PaO}_{2}$ was measured via ABG analysis and the increase was seen immediately following the application of the ARM. This improvement in $\mathrm{PaO}_{2}$ over the conventional preoxygenation group and NPPV alone group was sustained throughout the entire surgical procedure $(\mathrm{P}<0.0001)$. 
The study also evaluated the end expiratory lung volume (EELV) of participants. End expiratory lung volumes measurements were obtained while patients were awake, after tracheal intubation, and five minutes after the initiation of mechanical ventilation and application of the ARM. Awake end expiratory lung volumes were improved in the NPPV with ARM compared to the conventional preoxygenation group and comparable to the NPPV alone group (P 0.002). The close approximation of awake EELV between the NPPV alone group and the NPPV with ARM group can be attributed to the fact that the application of the ARM occurred after the induction of anesthesia and initiation of mechanical ventilation. The NPPV with ARM group had an improved EELV over both the conventional preoxygenation group and the NPPV alone group as soon as 5 minutes after the initiation of mechanical ventilation (P 0.002). An increase in EELV recruits collapsed alveoli minimizing atelectasis development, increasing FRC and the $\mathrm{O}_{2}$ reserve available in the lungs (Futier et al.).

When applying CASP to the Futier study (Appendix D, Table D-3) the aim of the study was clearly addressed. All participants were accounted for at the conclusion of the study. Participants were randomized into groups and study investigators were blinded to the treatment assignment. Participants were comparable in age, sex, and BMI. Aside from the experimental intervention, all patients had the same parameters for mechanical ventilation. Pressure support ventilation was utilized and adjusted to obtain a Vt of 8 $\mathrm{mL} / \mathrm{kg}$ of predicted body weight, a PEEP level of $6-8 \mathrm{~cm} \mathrm{H}_{2} \mathrm{O}$ and a fraction of inspired oxygen concentration of $100 \%$ (Futier et al.).

Treatment effect was not specifically mentioned in this RCT. The authors determined that NPPV followed by early ARM improved arterial oxygenation by as 
much as 50\% compared to conventional preoxygenation or NPPV alone (Futier et al., 2011). There were no untoward health effects reported from utilizing NPPV with an alveolar recruitment maneuver. The results of the study can be applied to the context of the adult obese patient undergoing general anesthesia with endotracheal intubation.

The prospective randomized control trial completed by Reinius et al., (2009) (Appendix B, Table B- 4) evaluated the difference between three groups undergoing general anesthesia for gastric bypass surgery. Group 1 consisted of the application of PEEP of $10 \mathrm{~cm} \mathrm{H}_{2} \mathrm{O}$ following intubation. Group 2 participants received an ARM of 55 $\mathrm{cm} \mathrm{H}_{2} \mathrm{O}$ for 10 seconds followed by ZEEP. Group 3 participants received an ARM of 55 $\mathrm{cm} \mathrm{H}_{2} \mathrm{O}$ for 10 seconds and the application of PEEP at $10 \mathrm{~cm} \mathrm{H}_{2} \mathrm{O}$. This RCT consisted of 30 obese patients with a BMI of $45 \pm 4 \mathrm{~kg} / \mathrm{m}^{2}$, randomized into three equal groups.

This RCT utilized ABG analysis, EELV measurement, and CT imaging to compare the different treatment modalities. The trial determined that the $\mathrm{PaO}_{2} / \mathrm{FiO}_{2}$ ratio returned to near awake levels in the ARM with $10 \mathrm{~cm} \mathrm{H}_{2} \mathrm{O}$ PEEP group (P 0.0065) compared to the PEEP alone group or the ARM alone group. This improvement was seen immediately following the application of the ARM and was sustained at all measured time intervals. This finding indicates that the participants in the ARM with PEEP group had improved ventilation-perfusion matching and arterial oxygenation compared to the participants in the other groups.

End expiratory lung volume was measured via spiral CT imaging. Computed tomography scans were completed while participants were awake and again 20 minutes after the application of the different ventilatory strategies (Reinius et al., 2009). The 
authors concluded that those treated with the ARM with the application of PEEP had an EELV that returned to near awake, non-anesthetized levels $(1,357 \pm 305 \mathrm{ml})(\mathrm{P}<$ 0.0001). Neither the PEEP alone group or the ARM with ZEEP group had EELV levels that were comparable to awake, non-anesthetized levels. This further demonstrated that those treated in the ARM with PEEP group had improved functional residual capacity which minimizes the development of atelectatic lung tissue.

Participants also received computed tomography imaging to directly evaluate for the development of atelectasis postoperatively. The imaging showed that those individuals treated in the ARM with PEEP had a greater percentage of normally aerated lung tissue (72 $\pm 9 \%$ ) and decreased percentage of nonaerated lung tissue (P 0.0015). These improvements were seen over the PEEP alone group and the ARM alone group. These findings indicate there is a synergistic effect on the prevention of atelectasis with the utilization of an ARM in conjunction with the application of PEEP.

When applying this RCT to the CASP checklist (Appendix D, Table D-4), the groups were similar in age, sex, and BMI. The participants were randomized, and researchers were blind to the treatment group. All participants were accounted for at the end of the study. Aside from the experimental intervention the groups were treated equally. Before induction all groups were preoxygenated with $100 \% \mathrm{O}_{2}$ for five minutes. Mechanical ventilation was accomplished using a Vt of $10 \mathrm{~mL} / \mathrm{kg}$ of predicted body weight with an initial respiratory rate of 12 breaths per minute and adjusted to maintain end tidal carbon dioxide level between 34 - 41 mmHg (Reinus et al.). 
The treatment effect was not specifically mentioned in the trial findings. These results can be applied to adult obese patients undergoing general anesthesia with mechanical ventilation. The authors concluded that an ARM immediately followed by the application PEEP increased EELV, increased respiratory system compliance, improved arterial oxygenation, and effectively opened atelectatic areas of the lungs (Reinius et al.).

The randomized control trial completed by Almarakbi et al. (2009) (Appendix B, Table B-5) consisted of 60 patients with a BMI $>30 \mathrm{~kg} / \mathrm{m}^{2}$ undergoing general anesthesia for laparoscopic bariatric banding surgery. The participants were randomized into one of four groups. Group 1 utilized $10 \mathrm{~cm} \mathrm{H}_{2} \mathrm{O}$ PEEP following endotracheal intubation with no ARM. Group 2 had an ARM of $40 \mathrm{~cm} \mathrm{H}_{2} \mathrm{O}$ held for 15 seconds one time following endotracheal intubation, prior to the initiation of mechanical ventilation. Group 3 participants had a one-time application of the same ARM utilized in Group 2, followed by the application of $10 \mathrm{~cm} \mathrm{H}_{2} \mathrm{O}$ PEEP. Group 4 subjects had the same ARM utilized in Group 2 and Group 3 with the addition of repeating the ARM every 10 minutes during the surgical procedure in conjunction with the application of $10 \mathrm{~cm} \mathrm{H}_{2} \mathrm{O}$ PEEP.

The RCT utilized ABG analysis at six different time intervals to evaluate arterial oxygenation. Lung compliance, the ability of the lung to stretch and expand, was calculated on a breath-by-breath basis via the anesthesia machine. Postoperative $\mathrm{SpO}_{2}$ was also measured in the PACU following the return of spontaneous ventilation and tracheal extubation.

Group 4, which was treated with the ARM repeating every 10 minutes and the addition of PEEP, had an arterial oxygenation the was improved and sustained at all time 
intervals compared to all other groups ( $\mathrm{P}<0.01)$. Group 3 had initial improvement of $\mathrm{PaO}_{2}$, but this improvement was not sustained throughout the surgical procedure. Group 1 and Group 2 showed no improvement of $\mathrm{PaO} 2$ ( $\mathrm{P}$ value $<0.01$ ). Participants treated in Group 4 had improved arterial oxygenation and thus more functional alveoli available to participate in gas exchange.

Postoperative oxygen saturation was measured in the PACU. Group 1 and Group 2 the average postoperative $\mathrm{SpO}_{2}$ was between $92-93 \%(\mathrm{P}<0.01)$. The postoperative $\mathrm{SpO}_{2}$ for Group 3 was 94 - 95\% ( $\left.<<0.01\right)$, while the $\mathrm{SpO}_{2}$ for group 4 was between 96 97\% ( $\mathrm{P}<0.01)$. This demonstrates that the participants treated with the ARM repeating every ten minutes and the application of $10 \mathrm{~cm} \mathrm{H}_{2} \mathrm{O}$ PEEP had improved ventilationperfusion matching and less atelectasis development compared to the other groups while undergoing general anesthesia with positive pressure ventilation.

Respiratory compliance was measured automatically via the Zeus Drager anesthesia machine. Respiratory compliance is a measure of the lungs ability to stretch and expand as well as a measure of the lungs elastic recoil (Almarakbi et al., 2009). The calculation for respiratory compliance is $C=$ Tidal Volume $\div$ Plateau Pressure PEEP (Almarakbi). The initial respiratory compliance prior to pneumoperitoneum was $48 \mathrm{ml} \mathrm{cm} \mathrm{H}_{2} \mathrm{O}^{-1}$. Following abdominal insufflation with carbon dioxide compliance decreased to $30 \mathrm{ml} \mathrm{cm} \mathrm{H}_{2} \mathrm{O}^{-1}$. The interventions in Group 1 and Group 2 showed no improvement in respiratory compliance $(\mathrm{P}<0.01)$. Compliance was improved in group 3 to $30-35 \mathrm{ml} \mathrm{cm} \mathrm{H}_{2} \mathrm{O}^{-1}$. However, this improvement was not sustained at all time intervals $(\mathrm{P}<0.01)$. Group 4 had compliance levels return to near pre-pneumoperitoneum levels of 40 - $45 \mathrm{ml} \mathrm{cm} \mathrm{H}_{2} \mathrm{O}^{-1}$. This improvement was seen as soon as the ARM was 
utilized and was sustained throughout the entire surgical procedure due to the recurrence of the ARM repeating every ten minutes $(\mathrm{P}<0.01)$. This reveals that the respiratory mechanics that are impaired by obesity and abdominal insufflation are effectively counterbalanced with the application of a recurring ARM and the addition of PEEP.

When applying this RCT to the CASP checklist (Appendix D, Table D-5) the study addressed a specific issue. The assignment of patients was randomized, and researchers were blind to the treatment groups. The groups were similar in age, sex, and BMI. Aside from the experimental interventions, groups were treated equally. Mechanical ventilation was accomplished via volume-control ventilation with a Vt of 10 $\mathrm{mL} / \mathrm{kg}$, and abdominal insufflation pressure was kept between $11-13 \mathrm{mmHg}$ for all patients (Almarakbi et al.).

The treatment effect was not specifically mentioned in this RCT. The findings can be applied to the adult obese patient undergoing general anesthesia. There were no deleterious health effects from the application of the ARM or PEEP. The investigators concluded that those participants treated in the ARM repeating every ten minutes with the application of PEEP had the best improvement of respiratory system compliance, improved $\mathrm{PaO}_{2}$ at all time intervals, and improved $\mathrm{PACU} \mathrm{SpO}_{2}$.

The prospective, cross-analytic, RCT completed by Remistico et al., (Appendix B, Table B-6) evaluated 30 participants with a BMI of $35.2 \pm 5.5 \mathrm{~kg} / \mathrm{m}^{2}$ undergoing general anesthesia for laparoscopic bariatric surgery. The participants were divided into two equal groups. The control group did not receive an ARM. The experimental group 
had an ARM utilizing $30 \mathrm{~cm} \mathrm{H}_{2} \mathrm{O}$ of PEEP with an inspiratory plateau pressure of $15 \mathrm{~cm}$ $\mathrm{H}_{2} \mathrm{O}$ for two minutes immediately following abdominal deflation of pneumoperitoneum.

Pulmonary function testing was completed on each participant preoperatively and on postoperative day one and two. Spirometry measurement included: forced vital capacity (FVC), forced expiratory volume in one second $\left(\mathrm{FEV}_{1}\right)$, maximum voluntary ventilation (MVV), peak expiratory flow (PEF), and forced expiratory flow (FEF $25-75 \%)$. All spirometric values were decreased in the control group on postoperative day one and two when compared to the values in the ARM group $(\mathrm{P}<0.001)$. This decrease in spirometry values of the control group correlate with a decrease in FRC and the development of intraoperative atelectasis.

Postoperative chest radiographs were obtained on all of the participants. Radiographic imaging of the control group demonstrated atelectasis in $40 \%$ of participants while $20 \%$ had evidence of pleural effusion $(\mathrm{P}<0.02)$. In comparison, the ARM group had zero participants with measurable atelectasis via chest radiograph and only $13 \%$ had evidence of pleural effusion $(\mathrm{P}<0.02)$. This decrease in measurable atelectasis indicated that there was more functional lung tissue available to participate in ventilation and the perfusion of oxygen.

The RCT also evaluated patients utilizing BORG dyspnea scale on postoperative day one and two. The BORG dyspnea scale is a subjective numerical scale where patients are asked to rate their perceived level of exertion and dyspnea while performing activities of daily living (CDC, 2015). Participants treated in the ARM group reported less perceived levels of exertion compared to the control group on both postoperative day one 
and two (P 0.001). Subjects treated in the ARM group had less subjective complaints of dyspnea postoperatively while performing activities of daily living.

When applying this RCT to the CASP checklist (Appendix D, Table D-6) the assignment of patients was randomized, and researchers were blind to the treatment groups. The groups were similar in age, sex, and BMI. Aside from the experimental intervention, the two groups were treated equally. Mechanical ventilation was accomplished the same way for all patients. All participants were accounted for at the end of the study.

The treatment effect was not specifically mentioned in the results of this study. The results can be applied to the context of the adult obese patient undergoing general anesthesia. Researchers determined that there was a 78\% reduction in pulmonary complications postoperatively in the ARM group compared to that of the control group (Remistico et al., 2011). Furthermore, subjects in the experimental group had less perceived shortness of breath measured via the BORG dyspnea scale when completing their activities of daily living.

\section{Cross-Study Analysis}

The cross-study analysis table (Appendix E) illustrates the protocol utilized for each study, as well as the major outcomes associated with the application of the individual alveolar recruitment maneuvers. The alveolar recruitment maneuver groups were associated with improved intraoperative oxygenation (Chalhoub, Talab, Futier, Reinus, \& Almarakbi). A decrease in the Alveolar-arterial oxygen concentration gradient 
was also established with the utilization of alveolar recruitment maneuvers (Chalhoub \& Talab)

The alveolar recruitment maneuver groups had a decrease in measurable atelectasis via CT imaging or chest radiographs (Talab, Reinus, \& Remistico). Additionally, ARM groups had increased end expiratory lung volumes, improving FRC (Futier \& Reinus). Improved lung compliance was demonstrated with the application of alveolar recruitment maneuvers (Almarakbi) and improved postoperative $\mathrm{SpO}_{2}$ measured in the PACU was associated with the use of intraoperative ARM (Talab \& Almarakbi). Alveolar recruitment maneuver application showed an improvement in spirometry values and a decrease in subjective complaints of dyspnea while completing activities of daily living (Remistico). The use of an ARM in conjunction with the application of PEEP showed a synergistic improvement in perioperative respiratory function compared to the use of an ARM or PEEP alone treatment strategy (Chalhoub, Talab, Reinus, \& Almarakbi). A recurring ARM repeated every ten minutes with the application of PEEP showed improved respiratory function compared to an ARM alone, PEEP alone, or a single ARM with the adjunct of PEEP (Almarakbi). None of the randomized control trials in this systematic review mention negative health effects as a result of the utilization of alveolar recruitment maneuvers or the application of PEEP.

Next, the summary and conclusion section will be discussed. 


\section{Summary and Conclusions}

The purpose of this systematic review was to determine if the use of alveolar recruitment maneuvers is a safe and effective strategy for the prevention of atelectasis and respiratory complications in the adult obese patient undergoing general anesthesia in the perioperative period. Background research was completed on the incidence of obesity and the complications associated with providing anesthesia to the adult obese patient.

A literature review was completed focusing on the epidemiology of obesity, the pulmonary complications associated with obesity, and alveolar recruitment maneuvers. The theoretical framework that outlined the process of completing this systematic review was determined by the 27-item checklist and four-phase flow diagram from PRISMA. Research involving the use of alveolar recruitment maneuvers in the adult obese patient was identified utilizing CINHAL, Pubmed, and Medline. Identified research was then screened for inclusion criteria and eligibility.

An individual study analysis was completed on the included studies. Study specific data tables were completed to adequately appraise the RCTs. Outcome specific data tables were completed to determine the effects on pulmonary function with the use of alveolar recruitment maneuvers. Following data extraction, the randomized control trials were evaluated utilizing the Critical Appraisal Skills Programme checklist to evaluate the validity of the results and determine if the results could be applied in the context of the adult obese patient undergoing general anesthesia with mechanical ventilation. Lastly, a cross-study analysis table was completed to compare the protocol utilized in each study and the outcomes associated with the use of the different alveolar recruitment maneuvers employed. 
There is extensive research on mechanical ventilation strategies used for managing the patient that requires endotracheal intubation with positive pressure ventilation. Alveolar recruitment maneuvers have been extensively researched and they are recommended for the reversal of anesthesia-induced atelectasis. Research on the use of alveolar recruitment maneuvers in the adult obese patient requiring anesthesia is available. However, the research identified was limited to patients undergoing either open or laparoscopic bariatric procedures. Research has demonstrated that alveolar recruitment maneuvers can be safely used in the obese patient, maintaining patency of the small airways, and improving ventilation-perfusion matching (Barash et al., 2013). There is limited research on the best timing of ARM utilization and if they should be consistently repeated as part of the anesthetic management for the adult obese patient.

There were several limitations identified in completing this systematic review. The aim of this systematic review was to determine if alveolar recruitment maneuvers are safe and effective for use in the adult obese patient. However, there are a limited number of studies evaluating these maneuvers in the adult obese patient. Several of the studies evaluated patients with a BMI $>40 \mathrm{~kg} / \mathrm{m}^{2}$, classifying them as morbidly obese not obese. The overall sample size across the six randomized control trials was small. The studies evaluated utilized different alveolar recruitment maneuvers that varied in the degree of positive pressure and the length of time the ARM was applied. Only one randomized control trial evaluated the usefulness of repeating the alveolar recruitment maneuver throughout the anesthetic.

The findings of this systematic review determined that the use of alveolar recruitment maneuvers improved intraoperative oxygenation and decreased the alveolar- 
arterial oxygen concentration gradient. Alveolar recruitment maneuvers decreased atelectasis measured via CT and chest radiographs. End-expiratory lung volumes were improved with the application of an ARM. Postoperative spirometry function was improved following the application of an intraoperative ARM. Recurring ARM with the application of PEEP improved respiratory function compared to a one-time ARM. There was a clear synergistic effect on improved respiratory function demonstrated with ARM usage in conjunction with the application of PEEP compared to an ARM alone or PEEP alone.

Next, the recommendations and implications for advanced nursing practice section will be discussed. 


\section{Recommendations and Implications for Advanced Nursing Practice}

With the induction of anesthesia, the degree of atelectasis development can increase up to $15 \%$ of the entire lung for all patients (Talab et al., 2009). Obesity is associated with a reduction of functional residual capacity (FRC), expiratory reserve volume (ERV), and total lung capacity (TLC) (Nagelhout \& Plause, 2014). These pathophysiologic changes associated with obesity reduce oxygen reserve and overall lung function. These changes place the obese patient at risk for perioperative atelectasis development and ventilation-perfusion mismatching. The application of ARM has demonstrated a reduction in atelectasis development and should be employed to reduce anesthesia-induced atelectasis and atelectasis that is a direct result of obesity.

Clinicians utilizing ARMs as part of their anesthetic management for obese patients need to have a clear understanding how these maneuvers impact the physiology of the obese patient. Increasing intrathoracic pressure with the application of an ARM could impede venous return, leading to hemodynamic compromise. Hemodynamic parameters should be monitored during ARM application. Hypotension or bradycardia resulting from the use of ARMs should be monitored and if substantial the ARM should be released.

Further research on which ARM is most beneficial to the obese patient and if these maneuvers should be routinely repeated throughout the anesthetic should be conducted. Research on the use of protective lung ventilation in conjunction with ARM usage could be beneficial in providing a more complete respiratory management strategy in caring for the adult obese patient. Research on the use of alveolar recruitment maneuvers in patients with obesity and underlying respiratory disease would be of benefit 
to determine if the maneuvers are deleterious to patients with further compromised respiratory function.

Educating clinicians on the pathophysiologic changes associated with obesity and the evidence-based care that they can provide to improve patient outcomes is essential. Facilities that routinely care for the obese population should implement an education and training program that incorporates specific treatments for this specific patient-population. Partnering and collaborating with stake-holders to improve patient care is the responsibility of all clinicians. Establishing guidelines on the application and use of alveolar recruitment maneuvers ensures that clinicians have the necessary knowledge and confidence to incorporate these maneuvers as part of their anesthetic practice for the obese patient.

Communication with the surgeon performing the procedure or the anesthesiologist participating in the anesthetic ensures those caring for the patient in the intraoperative period are prepared to manage the obese patient with a decreased respiratory reserve. Educating PACU nurses on the increased risk of respiratory compromise that is associated with obesity ensures that those at risk for postoperative respiratory distress due to obesity are closely monitored. Determining the best ventilatory strategy for managing the adult obese patient is paramount in limiting the respiratory compromise that is associated with obesity. 


\section{References}

American Society of Anesthesiologists. (2016). Obesity and anesthesia. Retrieved from https://www.asahq.org/whensecondscount/patients\%20home/preparing\%20for\%2 0surgery/surgery\%20risks/obesity\%20and\%20anesthesia

Almarakbi, W., Fawzi, H., Alhashemi, J., (2009). Effects of four intraoperative ventilatory strategies on respiratory compliance and gas exchange during laparoscopic gastric banding in obese patients. British Journal of Anesthesia, 102(6), $862-868$.

Barash, P., Culen, C., Stoelting, R., Cahalan, M., Stock, M., \& Ortega, R. (2013). Anesthesia and Obesity. Clinical Anesthesia, (pp. 1274 - 1293). Philadelphia, PA: Lippincott Williams

Centers for Disease Control and Prevention. (2016). Adult obesity causes and consequences. Retrieved from https://www.cdc.gov/obesity/adult/causes.html

Centers for Disease Control and Prevention. (2015). Perceived exertion, BORG rating of perceived exertion scale. Retrieved from https://www.cdc.gov/physicalactivity/basics/measuring/exertion.htm

Critical Appraisal Skills Programme. (2017). CASP systematic reviews checklist. Retrieved from http://docs.wixstatic.com/ugd/dded87_7e983a320087439e94533f4697aa109c.pdf

Dambaugh, L. A. (2016). Progressive care of obese patients. Critical Care Nurse, 36(4), 58-63. doi:10.4037/ccn2016510 
Domi, R., \& Laho, H. (2012). Anesthetic challenges in the obese patient. Journal of Anesthesia, 26(5), 758-765. doi:10.1007/s00540-012-1408-4.

Futier, E., Constanatin, JM., Pelosi, P., Chanques, G., Massone, A., Petit, A., Kwiatkowski, F., Bazin, JE., \& Jaber, S. (2011). Noninvasive ventilation and alveolar recruitment maneuvers improve respiratory function during and after intubation of morbidly obese patients. Anesthesiology, 114(6), 1354-1363.

Gertler, R. (2017). Mechanical ventilation during anesthesia in adults. Up To Date. Retrieved from: https://www.uptodate.com/contents/mechanical-ventilationduring-anesthesia-in-adults

Goode, V., Phillips, E., DeGuzman, P., Hinton, I., Rovnyak, V., Scully, K., \& Merwin, E. (2016). A patient safety dilemma: Obesity in the surgical patient. AANA Journal, 84(6) 404-412.

Imber, D. A., Pirrone, M., Zhang, C., Fisher, D. F., Kacmarek, R. M., \& Berra, L. (2016). Respiratory management of perioperative obese patients. Respiratory Care, 61(12), 1681-1692.

Jense, H., Dubin, S., Silverstein, P., \& O’Leary, U., (1991). Effect of obesity on safe duration of apnea in anesthetized humans. Anesth Analg,72, 89-93.

Kahlon, S., Eurich, D. T., Padwal, R. S., Malhotra, A., Minhas-Sandhu, J. K., Marrie, T. J., \& Majumdar, S. R. (2013). Obesity and outcomes in patients hospitalized with pneumonia. Clinical Microbiology and Infection: The Official Publication Of The 
European Society Of Clinical Microbiology And Infectious Diseases, 19(8), 709716. doi:10.1111/j.1469-0691.2012.04003.x

Liberati, A., Altman, DG., Tetzlaff, J., Mulrow, C., Gotzsche, PC., Ioannidis, JPA., Clarke, M., Devereaux, PJ., Kleijnen, J., \& Moher, D. (2009). The PRISMA statement for reporting systematic reviews and meta-analyses of studies that evaluate health care interventions: Explanation and elaboration. PLos Med, 6(7). Retrieved from http://prisma-statement.org

Miller, R., Cohen, N., Erikson, L., Fleisher, L., Wiener-Kronish, J., \& Young, W., (2015). Anesthesia for bariatric surgery. Millers Anesthesia (pp. 2200-2215). St Louis, MO: Elseveier Sainers

Nagelhout, J. \& Plaus, K. (2014). Respiratory anatomy, physiology, pathophysiology, and anesthetic management. Nurse Anesthesia (pp. 591-661). St Louis, MO: Elseveier Saunders.

National Institute of Health and Human Services. (2017). Overweight and obesity. Retrieved from https://www.nhlbi.nih.gov/health/health-topics/topics/obe

Reinius, H., Jonsson, L., Gustafsson, S., Sundbom, M., Duvernoy, O., Pelosi, P., Hedenstieerna, G., \& Freden, F. (2009). Prevention of atelectasis in morbidly obese patients during general anesthesia and paralysis. Anesthesiology, 111, (5), 979-987. 
Sagana, R., \& Hyzy, R. (2017). Positive end expiratory pressure. Up To Date. Retrieved from: https://www.uptodate.com/contents/positive-end-expiratory-pressurepeep?source=search_result\&search=peep\&selectedTitle=1 123

Salome, C., King, G., \& Berend, N. (2009). Physiology of obesity and effects on lung function. American Physiology Society, 108. 206-211.

Siegel, M., \& Hazy, R. (2017). Mechanical ventilation of adults in acute respiratory distress syndrome. Up to Date. Retrieved from https://www.uptodate.com/contents/mechanical-ventilation-of-adults-in-acuterespiratory-distress-syndrome

Talab, H., Zabani, I., Abdelrahman, H., Bukhari, W., Mamoun, I., Ashour, M., Sadeq, B., \& Sayed, S. (2009). Intraoperative ventilatory strategies for the prevention of pulmonary atelectasis in obese patients undergoing laparoscopic bariatric surgery. Anesthesia \& Analgesia, 109(5), 1511-1516.

Thompson, J., Bordi, S., Boytim, M., Elisha, S., Heiner, J., \& Nagelhout, J. (2011). Anesthesia case management for bariatric surgery. AANA Journal, 79 (2), 147158.

World Health Organization. (2017). WHO ten facts on obesity. Retrieved from http://www.who.int/features/factfiles/obesity/facts/en/ 


\section{Appendix A}

\begin{tabular}{|c|c|c|c|}
\hline Section/topic & $\#$ & Checklist item & $\begin{array}{l}\text { Reported } \\
\text { on page \# }\end{array}$ \\
\hline \multicolumn{4}{|l|}{ TITLE } \\
\hline Title & 1 & Identify the report as a systematic review, meta-analysis, or both. & \\
\hline \multicolumn{4}{|l|}{ ABSTRACT } \\
\hline $\begin{array}{l}\text { Structured } \\
\text { summary }\end{array}$ & 2 & $\begin{array}{l}\text { Provide a structured summary including, as applicable: background; objectives; data sources; study eligibility } \\
\text { criteria, participants, and interventions; study appraisal and synthesis methods; results; limitations; conclusions } \\
\text { and implications of key findings; systematic review registration number. }\end{array}$ & \\
\hline \multicolumn{4}{|l|}{ INTRODUCTION } \\
\hline Rationale & 3 & Describe the rationale for the review in the context of what is already known. & \\
\hline Objectives & 4 & $\begin{array}{l}\text { Provide an explicit statement of questions being addressed with reference to participants, interventions, } \\
\text { comparisons, outcomes, and study design (PICOS). }\end{array}$ & \\
\hline \multicolumn{4}{|l|}{ METHODS } \\
\hline $\begin{array}{l}\text { Protocol and } \\
\text { registration }\end{array}$ & 5 & $\begin{array}{l}\text { Indicate if a review protocol exists, if and where it can be accessed (e.g., Web address), and, if available, provide } \\
\text { registration information including registration number. }\end{array}$ & \\
\hline Eligibility criteria & 6 & $\begin{array}{l}\text { Specify study characteristics (e.g., PICOS, length of follow-up) and report characteristics (e.g., years considered, } \\
\text { language, publication status) used as criteria for eligibility, giving rationale. }\end{array}$ & \\
\hline $\begin{array}{l}\text { Information } \\
\text { sources }\end{array}$ & 7 & $\begin{array}{l}\text { Describe all information sources (e.g., databases with dates of coverage, contact with study authors to identify } \\
\text { additional studies) in the search and date last searched. }\end{array}$ & \\
\hline Search & 8 & $\begin{array}{l}\text { Present full electronic search strategy for at least one database, including any limits used, such that it could be } \\
\text { repeated. }\end{array}$ & \\
\hline Study selection & 9 & $\begin{array}{l}\text { State the process for selecting studies (i.e., screening, eligibility, included in systematic review, and, if applicable, } \\
\text { included in the meta-analysis). }\end{array}$ & \\
\hline $\begin{array}{l}\text { Data collection } \\
\text { process }\end{array}$ & 10 & $\begin{array}{l}\text { Describe method of data extraction from reports (e.g., piloted forms, independently, in duplicate) and any } \\
\text { processes for obtaining and confirming data from investigators. }\end{array}$ & \\
\hline Data items & 11 & $\begin{array}{l}\text { List and define all variables for which data were sought (e.g., PICOS, funding sources) and any assumptions and } \\
\text { simplifications made. }\end{array}$ & \\
\hline $\begin{array}{l}\text { Risk of bias in } \\
\text { individual studies }\end{array}$ & 12 & $\begin{array}{l}\text { Describe methods used for assessing risk of bias of individual studies (including specification of whether this was } \\
\text { done at the study or outcome level), and how this information is to be used in any data synthesis. }\end{array}$ & \\
\hline $\begin{array}{l}\text { Summary } \\
\text { measures }\end{array}$ & 13 & State the principal summary measures (e.g., risk ratio, difference in means). & \\
\hline $\begin{array}{l}\text { Synthesis of } \\
\text { results }\end{array}$ & 14 & $\begin{array}{l}\text { Describe the methods of handling data and combining results of studies, if done, including measures of } \\
\text { consistency }\left(\mathrm{e} . \mathrm{g} . \mathrm{I}^{2}\right) \text { for each meta-analysis. }\end{array}$ & \\
\hline $\begin{array}{l}\text { Risk of bias } \\
\text { across studies }\end{array}$ & 15 & $\begin{array}{l}\text { Specify any assessment of risk of bias that may affect the cumulative evidence (e.g., publication bias, selective } \\
\text { reporting within studies). }\end{array}$ & \\
\hline $\begin{array}{l}\text { Additional } \\
\text { analyses }\end{array}$ & 16 & $\begin{array}{l}\text { Describe methods of additional analyses (e.g., sensitivity or subgroup analyses, meta-regression), if done, } \\
\text { indicating which were pre-specified. }\end{array}$ & \\
\hline \multicolumn{4}{|l|}{ RESULTS } \\
\hline Study selection & 17 & $\begin{array}{l}\text { Give numbers of studies screened, assessed for eligibility, and included in the review, with reasons for exclusions } \\
\text { at each stage, ideally with a flow diagram. }\end{array}$ & \\
\hline $\begin{array}{l}\text { Study } \\
\text { characteristics }\end{array}$ & 18 & $\begin{array}{l}\text { For each study, present characteristics for which data were extracted (e.g., study size, PICOS, follow-up period) } \\
\text { and provide the citations. }\end{array}$ & \\
\hline $\begin{array}{l}\text { Risk of bias } \\
\text { within studies }\end{array}$ & 19 & Present data on risk of bias of each study and, if available, any outcome level assessment (see item 12). & \\
\hline $\begin{array}{l}\text { Results of } \\
\text { individual studies }\end{array}$ & 20 & $\begin{array}{l}\text { For all outcomes considered (benefits or harms), present, for each study: (a) simple summary data for each } \\
\text { intervention group (b) effect estimates and confidence intervals, ideally with a forest plot. }\end{array}$ & \\
\hline $\begin{array}{l}\text { Synthesis of } \\
\text { results }\end{array}$ & 21 & Present results of each meta-analysis done, including confidence intervals and measures of consistency. & \\
\hline $\begin{array}{l}\text { Risk of bias } \\
\text { across studies }\end{array}$ & 22 & Present results of any assessment of risk of bias across studies (see Item 15). & \\
\hline $\begin{array}{l}\text { Additional } \\
\text { analysis }\end{array}$ & 23 & $\begin{array}{l}\text { Give results of additional analyses, if done (e.g., sensitivity or subgroup analyses, meta-regression [see Item } \\
\text { 16]). }\end{array}$ & \\
\hline \multicolumn{4}{|l|}{ DISCUSSION } \\
\hline $\begin{array}{l}\text { Summary of } \\
\text { evidence }\end{array}$ & 24 & $\begin{array}{l}\text { Summarize the main findings including the strength of evidence for each main outcome; consider their relevance } \\
\text { to key groups (e.g., healthcare providers, users, and policy makers). }\end{array}$ & \\
\hline Limitations & 25 & $\begin{array}{l}\text { Discuss limitations at study and outcome level (e.g., risk of bias), and at review-level (e.g., incomplete retrieval of } \\
\text { identified research, reporting bias). }\end{array}$ & \\
\hline Conclusions & 26 & $\begin{array}{l}\text { Provide a general interpretation of the results in the context of other evidence, and implications for future } \\
\text { research. }\end{array}$ & \\
\hline \multicolumn{4}{|l|}{ FUNDING } \\
\hline Funding & 27 & $\begin{array}{l}\text { Describe sources of funding for the systematic review and other support (e.g., supply of data); role of funders for } \\
\text { the systematic review. }\end{array}$ & \\
\hline
\end{tabular}




\section{Appendix B}

Table B-1

Study Specific Data

Chalhoub, V., Yazigi, A., Sleilaty, G., Haddad, F., Noun, R., Madi-Jebra, S., \& Yazbeck, P., (2007). Effect of vital capacity manoeuvers on arterial oxygenation in morbidly obese patients undergoing open bariatric surgery. European Journal of Anesthesiology, 24, $283-288$.

\begin{tabular}{|c|c|c|c|c|c|}
\hline$\underline{\text { Aim }}$ & Design & $\underline{\text { Site }}$ & Sample & Method & Outcomes \\
\hline $\begin{array}{l}\text { Evaluate the effect } \\
\text { of vital capacity } \\
\text { maneuver followed } \\
\text { by ventilation with } \\
\text { PEEP, on arterial } \\
\text { oxygenation in } \\
\text { obese patients } \\
\text { undergoing open } \\
\text { bariatric surgery. }\end{array}$ & 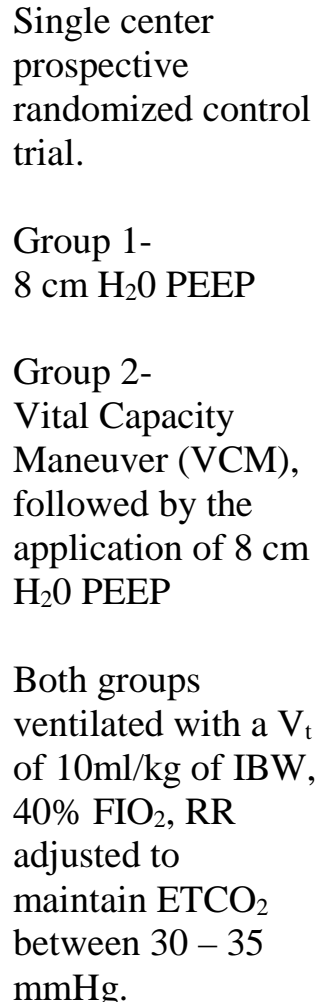 & $\begin{array}{l}\text { Hotel Dieu de } \\
\text { France Hospital, } \\
\text { Department of } \\
\text { Anesthesia and } \\
\text { Critical Care; } \\
\text { Department of } \\
\text { General Surgery, } \\
\text { Beirut, Lebanon. }\end{array}$ & $\begin{array}{l}52 \text { obese patients } \\
\text { with a BMI }>40 \\
\mathrm{~kg} / \mathrm{m}^{2} \text { divided in to } \\
\text { two equal groups. } \\
\text { All patients had an } \\
\text { ASA grade of III. }\end{array}$ & $\begin{array}{l}\text { Hemodynamic and } \\
\text { respiratory } \\
\text { parameters } \\
\text { measured: MAP, } \\
\mathrm{HR}_{\text {, ETCO }} \text {, } \\
{\text { PaCO2, PIP, } \mathrm{V}_{\mathrm{T}}} \\
\text { RR. Measured at } \\
\text { three-time intervals. } \\
\text { T0= Before } \\
\text { application of } \\
\text { VCM/and or PEEP. } \\
\text { T1= } 5 \text { minutes after } \\
\text { application of } \\
\text { VCM/and or PEEP. } \\
\text { T2= Before } \\
\text { abdominal closure. }\end{array}$ & $\begin{array}{l}\mathrm{SaO}_{2}, \mathrm{PaO}_{2} \text {, and } \mathrm{A}- \\
\mathrm{aDO}_{2} \text {. }\end{array}$ \\
\hline
\end{tabular}




\section{Appendix B}

Table B-2

Study Specific Data

Talab, H., Zabani, I., Abdelrahman, H., Bukhari, W., Mamoun, I., Ashour, M., Sadeq, B., \& Sayed, S. (2009). Intraoperative ventilatory strategies for the prevention of pulmonary atelectasis in obese patients undergoing laparoscopic bariatric surgery.

Anesthesia \& Analgesia, 109, (5), 1511-1516.

\begin{tabular}{|c|c|c|c|c|c|}
\hline Aim & Design & Site & Sample & Method & Outcomes \\
\hline $\begin{array}{l}\text { To determine if the } \\
\text { utilization of an } \\
\text { ARM with the } \\
\text { application of } \\
\text { PEEP improved } \\
\text { arterial oxygenation } \\
\text { and decreased the } \\
\text { development of } \\
\text { atelectasis } \\
\text { compared to ARM } \\
\text { with ZEEP in obese } \\
\text { patients undergoing } \\
\text { laparoscopic } \\
\text { bariatric surgery. }\end{array}$ & $\begin{array}{l}\text { Prospective, } \\
\text { double-blind, } \\
\text { randomized } \\
\text { controlled study } \\
\text { Group 1: } \\
\text { VCM for 7-8 s + } \\
\text { ZEEP. } \\
\text { Group 2: } \\
\text { VCM for } 7-8 \mathrm{~s}+ \\
\text { PEEP of } 5 \mathrm{~cm} \mathrm{H}_{2} \mathrm{O} \text {. } \\
\text { Group } 3 \text { : } \\
\text { VCM for } 7-8 \mathrm{~s}+ \\
\text { PEEP of } 10 \mathrm{~cm} \\
\mathrm{H}_{2} \mathrm{O} \text {. }\end{array}$ & $\begin{array}{l}\text { Department of } \\
\text { Anesthesiology, } \\
\text { General Surgery, } \\
\text { Radiology, } \\
\text { Biostatistics, and } \\
\text { Cardiothoracic } \\
\text { Surgery, King } \\
\text { Faisal Specialist } \\
\text { Hospital and } \\
\text { Research Center, } \\
\text { Jeddah, Saudi } \\
\text { Arabia. }\end{array}$ & $\begin{array}{l}66 \text { adult obese patients } \\
\text { with a BMI between } \\
30- \\
50 \mathrm{~kg} / \mathrm{m}^{2} \text {. } \\
\text { Placed into three equal } \\
\text { groups ( } \mathrm{n}=22 \text {, for each } \\
\text { of the three groups). }\end{array}$ & $\begin{array}{l}\text { Pharmacological } \\
\text { induction of } \\
\text { anesthesia was } \\
\text { completed in the } \\
\text { same way for all } \\
\text { groups. } \\
\text { Ventilator } \\
\text { settings were the } \\
\text { same for all } \\
\text { groups. } \\
\text { HR, MAP, PaO2, } \\
\text { SaO,, A-a } \\
\text { Gradient. Time } \\
\text { intervals T0 - T8. } \\
\text { CT scans } \\
\text { completed to } \\
\text { evaluate for } \\
\text { atelectasis. }\end{array}$ & $\begin{array}{l}\text { PACU length of } \\
\text { stay, need for } 100 \% \\
\mathrm{O}_{2} \text { in the PACU, A- } \\
\text { a } \mathrm{DO}_{2} \text { gradient, } \\
\text { postoperative } \\
\text { pulmonary } \\
\text { complications, and } \\
\text { degree of atelectasis } \\
\text { seen on pulmonary } \\
\text { CT scan. }\end{array}$ \\
\hline
\end{tabular}

Note. ZEEP- zero end-expiratory pressure. 


\section{Appendix B}

Table B-3

\section{Study Specific Data}

Futier, E., Constanatin, JM., Pelosi, P., Chanques, G., Massone, A., Petit, A., Kwiatkowski, F., Bazin, JE., \& Jaber, S. (2011). Noninvasive ventilation and alveolar recruitment maneuvers improve respiratory function during and after intubation of morbidly obese patients. Anesthesiology, 114, (6), 1354-1363.

\begin{tabular}{|c|c|c|c|c|c|}
\hline$\underline{\text { Aim }}$ & Design & $\underline{\text { Site }}$ & Sample & Method & Outcomes \\
\hline $\begin{array}{l}\text { To determine } \\
\text { whether } \\
\text { noninvasive } \\
\text { positive pressure } \\
\text { ventilation (NPPV) } \\
\text { improves } \\
\text { oxygenation and } \\
\text { end-expiratory } \\
\text { lung volume more } \\
\text { efficiently than } \\
\text { conventional } \\
\text { methods and } \\
\text { whether NPPV } \\
\text { followed by ARM } \\
\text { further improves } \\
\text { respiratory } \\
\text { function in patients } \\
\text { undergoing a } \\
\text { laparoscopic sleeve }\end{array}$ & $\begin{array}{l}\text { Prospective } \\
\text { randomized control } \\
\text { study. } \\
\text { Patients placed into } \\
3 \text { equal groups } \\
\text { (n=66). } \\
\text { Group } 1 \text { - } \\
5 \text { minutes of } \\
\text { preoxygenation } \\
\text { with } 100 \% \mathrm{O}_{2} \text {. } \\
\text { Group } 2 \text { - NPPV } \\
\text { alone. } \\
\text { Group } 3 \text { - } \\
\text { NPPV followed by } \\
\text { ARM }\end{array}$ & $\begin{array}{l}\text { Department of } \\
\text { Anesthesiology and } \\
\text { Critical Care } \\
\text { Medicine, Estaing } \\
\text { Hospital, } \\
\text { University Hospital } \\
\text { of Clermont- } \\
\text { Ferrand, Clermont- } \\
\text { Ferrand, France. }\end{array}$ & $\begin{array}{l}66 \text { adult obese } \\
\text { patients with a } \\
\text { BMI of } 46 \pm 6 \\
\mathrm{~kg} / \mathrm{m}^{2} . \\
\text { ASA II - III. }\end{array}$ & $\begin{array}{l}\mathrm{PaO}_{2} \text { was measured } \\
\text { awake at the end of } \\
\text { preoxygenation, } \\
\text { immediately } \\
\text { following } \\
\text { endotracheal } \\
\text { intubation, and } 5 \\
\text { minutes after } \\
\text { mechanical } \\
\text { ventilation. } \\
\text { EELV was } \\
\text { measured awake, } \\
\text { following } \\
\text { intubation, and } 5 \\
\text { minutes after } \\
\text { mechanical } \\
\text { ventilation. }\end{array}$ & $\mathrm{PaO}_{2}$ and EELV. \\
\hline
\end{tabular}

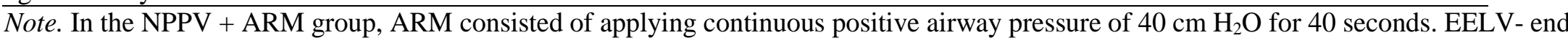
expiratory lung volume. 
Table B-4

\section{Appendix B}

Study Specific Data

Reinius, H., Jonsson, L., Gustafsson, S., Sundbom, M., Duvernoy, O., Pelosi, P., Hedenstieerna, G., \& Freden, F. (2009).

Prevention of atelectasis in morbidly obese patients during general anesthesia and paralysis. Anesthesiology, 111, (5), 979987.

\begin{tabular}{|c|c|c|c|c|c|}
\hline$\underline{\text { Aim }}$ & $\underline{\text { Design }}$ & $\underline{\text { Site }}$ & $\underline{\text { Sample }}$ & Method & Outcomes \\
\hline $\begin{array}{l}\text { To determine if the } \\
\text { utilization of and } \\
\text { ARM + PEEP } 10 \\
\mathrm{~cm} \mathrm{H}_{2} 0 \text { improved } \\
\text { respiratory function } \\
\text { compared to ARM } \\
\text { or PEEP alone in } \\
\text { patients undergoing } \\
\text { gastric bypass } \\
\text { surgery. }\end{array}$ & $\begin{array}{l}\text { Prospective } \\
\text { randomized control } \\
\text { trial consisting of } 3 \\
\text { groups. } \\
\text { Group } 1 \text { - PEEP of } \\
10 \mathrm{~cm} \mathrm{H}_{2} 0 \text {. } \\
\text { Group } 2 \text { - ARM } \\
\text { followed by ZEEP. } \\
\text { Group } 3 \text { - ARM + } \\
\text { PEEP of } 10 \mathrm{~cm} \\
\mathrm{H}_{2} \mathrm{O} \text {. }\end{array}$ & $\begin{array}{l}\text { Department of } \\
\text { Anesthesia and } \\
\text { Intensive Care, } \\
\text { University Hospital, } \\
\text { Uppsala, Sweden. }\end{array}$ & $\begin{array}{l}30 \text { obese patients } \\
\text { with BMI } 45 \pm 4 \\
\mathrm{~kg} / \mathrm{m}^{2} \text {. } \\
\text { ASA II - III. }\end{array}$ & $\begin{array}{l}\text { CT scans were } \\
\text { completed awake, } \\
\text { after induction, and } \\
\text { after intervention. } \\
\text { ABG analysis was } \\
\text { completed awake, at } \\
\text { induction, 5, 20, and } \\
40 \text { minutes post } \\
\text { induction. } \\
\text { Before induction of } \\
\text { anesthesia all } \\
\text { groups were } \\
\text { preoxygenated with } \\
100 \% \mathrm{O}_{2} \text { for } 5 \\
\text { minutes. } \\
\mathrm{MV} \mathrm{parameters:}^{\mathrm{V}_{\mathrm{T}} 10 \mathrm{ml} / \mathrm{kg}, \mathrm{RR}} \\
\text { adjusted to maintain } \\
\text { ETCO } 34-41 \\
\text { mmHg. }\end{array}$ & $\begin{array}{l}\mathrm{PaO}_{2} / \mathrm{FiO}_{2} \text { ratio, } \\
\text { EELV, and degree } \\
\text { of normal } \\
\text { pulmonary aeration } \\
\text { seen via CT scan. }\end{array}$ \\
\hline
\end{tabular}

Note. ARM consisted of inspiratory pressure increased to $55 \mathrm{~cm} \mathrm{H}_{2} \mathrm{O}$ and held for 10 seconds. 
Table B-5

\section{Appendix B}

Study Specific Data

Almarakbi, W., Fawzi, H., Alhashemi, J., (2009). Effects of four intraoperative ventilatory strategies on respiratory compliance and gas exchange during laparoscopic gastric banding in obese patients. British Journal of Anesthesia, 102 (6), $862-868$.

\begin{tabular}{|c|c|c|c|c|c|}
\hline$\underline{\text { Aim }}$ & Design & $\underline{\text { Site }}$ & $\underline{\text { Sample }}$ & Method & Outcomes \\
\hline $\begin{array}{l}\text { To determine which } \\
\text { of four ventilatory } \\
\text { strategies improves } \\
\text { respiratory } \\
\text { compliance and } \\
\text { arterial partial } \\
\text { pressure of oxygen } \\
\left(\mathrm{PaO}_{2}\right) \text { in obese } \\
\text { patients undergoing } \\
\text { laparoscopic } \\
\text { banding. }\end{array}$ & $\begin{array}{l}\text { Randomized control } \\
\text { trial. } \\
\text { Group 1- PEEP } 10 \\
\mathrm{~cm} \mathrm{H}_{2} 0 \text {. } \\
\text { Group 2- ARM of } \\
40 \mathrm{~cm} \mathrm{H}_{2} \mathrm{O} \text { for } 15 \mathrm{~s} \\
\text { (once). } \\
\text { Group } 3 \text { - ARM of } \\
40 \text { cm } \mathrm{H}_{2} \mathrm{O} \text { for } 15 \mathrm{~s} \\
\text { (once) followed by } \\
\text { PEEP } 10 \text { cm } \mathrm{H}_{2} 0 \text {. } \\
\\
\text { Group } 4-\text { ARM of } \\
40 \text { cm } \mathrm{H}_{2} \mathrm{O} \text { for } 15 \mathrm{~s} \\
\text { (repeated every } 10 \\
\text { minutes) }+ \text { PEEP } 10 \\
\text { cm } \mathrm{H}_{2} 0 \text {. }\end{array}$ & $\begin{array}{l}\text { Department of } \\
\text { Anesthesia, Ain } \\
\text { Shams University, } \\
\text { Cairo, Egypt. } \\
\text { Department of } \\
\text { Anesthesia and } \\
\text { Critical Care, King } \\
\text { Abdulaziz } \\
\text { University, Jeddah, } \\
\text { Saudi Arabia. }\end{array}$ & $\begin{array}{l}60 \text { patients with a } \\
\text { BMI >30 kg/m². } \\
\text { ASA II }\end{array}$ & $\begin{array}{l}\text { Respiratory } \\
\text { compliance and } \\
\mathrm{PaO}_{2} \text { were } \\
\text { determined } 5 \\
\text { minutes after } \\
\text { intubation, } 10 \\
\text { minutes after } \\
\text { pneumoperitoneum, } \\
\text { and every } 10 \\
\text { minutes after ARM. } \\
\text { Respiratory } \\
\text { management was } \\
\text { the same for all } \\
\text { patients except for } \\
\text { variables being } \\
\text { evaluated. } \\
\text { Pneumoperitoneum } \\
\text { was maintained } \\
\text { between 11-13 } \\
\text { mmHg for all } \\
\text { patients. }\end{array}$ & $\begin{array}{l}\text { Respiratory } \\
\text { compliance, } \mathrm{PaO}_{2} \text {, } \\
\text { and PACU SpO} 2 \text {. }\end{array}$ \\
\hline
\end{tabular}


Table B-6

\section{Appendix B}

Study Specific Data

Remistico, P., Araujo, S., Castilho de Figueiredu, L., Aquim, E., Gomes, L., Sombrio, M., Ambiel, S., (2011). Impact of alveolar

recruitment maneuver in the postoperative period of videolaparoscopic bariatric surgery. Revista Brasileeira de Anestesiologia, 61 (2).

Aim

Evaluate the impact of ARM performed intraoperatively on patients undergoing

laparoscopic

bariatric surgery.
Design

Randomized clinical trial with a crossanalytic, prospective design.

Group 1- control group (No ARM).

Group 2- ARM

PEEP $30 \mathrm{~cm} \mathrm{H}_{2} \mathrm{O}$

and inspiratory

plateau pressure of

$45 \mathrm{~cm} \mathrm{H}_{2} 0$ after

deflation of

pneumoperitoneum. $\underline{\text { Sample }}$

30 patients with a BMI $35.2 \pm 5.5$

$\mathrm{kg} / \mathrm{m}^{2}$.
Hospital Vita Bate Curitiba, Parana, Brazil.

(

Method
PFT's were
completed pre and
postoperatively.

Chest radiographs were completed pre and postoperatively.

Dyspnea BORG scale completed POD \#1 and POD \#2.

Hemodynamic and respiratory parameters were recorded at 4-time intervals.

Respiratory management was the same except for variable being evaluated.

Outcomes

Spirometry values, chest radiographs, and BORD dyspnea scale. 
Table C-1

\section{Appendix C}

Outcome Data Collection

Chalhoub, V., Yazigi, A., Sleilaty, G., Haddad, F., Noun, R., Madi-Jebra, S., \& Yazbeck, P., (2007). Effect of vital capacity manoeuvers on arterial oxygenation in morbidly obese patients undergoing open bariatric surgery. European Journal of Anesthesiology, 24, 283-288.

PEEP (n=26) $\quad$ VCM + PEEP $(n=26) \quad P$-value

$\mathrm{SaO}_{2}$

(\%)

$\mathrm{PaO}_{2}$

(mmHg)

A-a $\mathrm{DO}_{2}$

(mmHg)
$\mathrm{T} 197.5 \pm 1.7$

T2 $98.5 \pm .9$

$\mathrm{T} 1110.0 \pm 35.3$

T2 $140.9 \pm 43.2$

$\mathrm{T} 1134.1 \pm 36.5$

T2 $104.9 \pm 41.9$

\section{$\mathrm{T} 198.8 \pm .7$}

T2 $98.9 \pm .7$

$\mathrm{T} 1170.6 \pm 46.6$

T2 $182.0 \pm 32.4$

$\mathrm{T} 177.4 \pm 48.3$

T2 $65.4 \pm 32.5$
$P$-value

0.035

0.001

0.001

Note. $\mathrm{SaO}_{2}$ is the percent of oxygen bound to hemoglobin. $\mathrm{PaO}_{2}$ is the arterial oxygen partial pressure. A-a $\mathrm{DO}_{2}$ is the Alveolararterial oxygen difference. The VCM + PEEP group had an increased $\mathrm{PaO}_{2}, \mathrm{SaO}_{2}$, and decreased Alveolar-arterial gradient at T1 and T2. Statistical significance was accepted at a $P$ value less than 0.05 . 


\section{Appendix C}

Table C-2

Outcome Data Collection

Talab, H., Zabani, I., Abdelrahman, H., Bukhari, W., Mamoun, I., Ashour, M., Sadeq, B., \& Sayed, S. (2009). Intraoperative ventilatory strategies for the prevention of pulmonary atelectasis in obese patients undergoing laparoscopic bariatric surgery. Anesthesia \&

Analgesia, 109, (5), 1511-1516.

\begin{tabular}{|c|c|c|c|c|}
\hline & $\begin{array}{r}\mathrm{VCM}+\mathrm{PEEP} \\
10 \mathrm{~cm} \mathrm{H} 20\end{array}$ & $\begin{array}{r}\mathrm{VCM}+\mathrm{PEEP} \\
5 \mathrm{~cm} \mathrm{H} 2 \mathrm{O}\end{array}$ & VCM + ZEEP & $P$-value \\
\hline PACU LOS (min) & $66.9 \pm 18.6$ & $77.5 \pm 20.35$ & $87.5 \pm 35.31$ & $<0.05$ \\
\hline $\begin{array}{l}\text { Need for } 100 \% \mathrm{O}_{2} \\
\text { in PACU }(\%)\end{array}$ & $1(4.5 \%)$ & $3(16.7 \%)$ & $5(26.3 \%)$ & $<0.05$ \\
\hline $\begin{array}{l}\text { A-a } \mathrm{O}_{2} \\
(\mathrm{mmHg})\end{array}$ & $29.85 \pm 18.83$ & $53.05 \pm 30.42$ & $63.23 \pm 35.12$ & $<0.05$ \\
\hline $\begin{array}{l}\text { CT Imaging } \\
\text { Normal } \\
\text { Lamellar } \\
\text { Plate Segmental } \\
\text { Lobar }\end{array}$ & $\begin{array}{r}2(10 \%) \\
11(55 \%) \\
3(15 \%) \\
4(20 \%) \\
0(0 \%)\end{array}$ & $\begin{array}{r}0(0 \%) \\
4(21 \%) \\
6(31.57 \%) \\
9(47.3 \%) \\
0(0 \%)\end{array}$ & $\begin{array}{r}0(0 \%) \\
2(10.5 \%) \\
3(15.78 \%) \\
13(68.42 \%) \\
1(5.26 \%)\end{array}$ & $<0.05$ \\
\hline $\begin{array}{l}\text { Pulmonary } \\
\text { Complications }\end{array}$ & 0 & 3 & 4 & \\
\hline
\end{tabular}




\section{Appendix C}

Table C-3

\section{Outcome Data Collection}

Futier, E., Constanatin, JM., Pelosi, P., Chanques, G., Massone, A., Petit, A., Kwiatkowski, F., Bazin, JE., \& Jaber, S. (2011). Noninvasive ventilation and alveolar recruitment maneuvers improve respiratory function during and after intubation of morbidly obese patients. Anesthesiology, 114, (6), 1354-1363.

\begin{tabular}{|c|c|c|c|c|}
\hline & Conventional Group & NPPV Group & NPPV + ARM Group & $P$ value \\
\hline $\begin{array}{l}\text { Intubation } \\
\mathrm{PaO}_{2} \text { (mmHg) }\end{array}$ & $306 \pm 51$ & $382 \pm 87$ & $375 \pm 82$ & 0.03 \\
\hline $\begin{array}{l}5 \text { min after } \\
\mathrm{ETI} \text { and } \mathrm{MV} \\
\mathrm{PaO}_{2}(\mathrm{mmHg})\end{array}$ & $93 \pm 25$ & $128 \pm 54$ & $234 \pm 73$ & $<0.0001$ \\
\hline $\begin{array}{l}\text { Awake EELV } \\
(\%)\end{array}$ & $58 \%$ & $88 \%$ & $87 \%$ & 0.002 \\
\hline $\begin{array}{l}5 \text { min after } \\
\text { ETI and MV } \\
\text { EELV (mL/kg } \\
\text { PBW) }\end{array}$ & 20 & 35 & 40 & 0.002 \\
\hline
\end{tabular}

Note. All patients had PFT's completed 1-2 days before surgery. Awake EELV measurements were obtained using the helium dilutional method. Subsequent EELV measurements were obtained via an automated procedure available on the ventilator. Increased EELV recruits collapsed alveoli, increasing oxygen reserve in the lungs. There was no significant difference in preoperative EELV or $\mathrm{PaO}_{2}$ values between groups. Postoperative respiratory complications were defined as the need for continued mechanical ventilation. $P$ values less than 0.05 were considered statistically significant. 
Table C-4

\section{Appendix C}

Outcome Data Collection

Reinius, H., Jonsson, L., Gustafsson, S., Sundbom, M., Duvernoy, O., Pelosi, P., Hedenstieerna, G., \& Freden, F. (2009). Prevention of atelectasis in morbidly obese patients during general anesthesia and paralysis. Anesthesiology, 111, (5), 979-987.

$$
\text { PEEP }
$$

$$
\begin{gathered}
(n=10) \\
432 \pm 68 \\
264 \pm 96 \\
267 \pm 94 \\
253 \pm 87 \\
262 \pm 88
\end{gathered}
$$

$(n=6)$

$823 \pm 206$

$1,085 \pm 304$

$$
(n=6)
$$

(Total Lung \%)
Normal Aeration

Poor Aeration

Nonaerated

$$
\begin{array}{r}
64 \pm 11 \\
30 \pm 10 \\
7 \pm 3
\end{array}
$$

$$
\text { ARM + PEEP }
$$

$P$ value

$$
\begin{gathered}
(n=10) \\
410 \pm 43 \\
225 \pm 77 \\
252 \pm 86 \\
225 \pm 82 \\
217+83
\end{gathered}
$$

$$
(n=6)
$$

$818 \pm 259$

$805 \pm 215$

$$
(n=6)
$$

$$
(n=10)
$$

$$
416 \pm 48
$$$$
266 \pm 70
$$

$$
419 \pm 106
$$$$
412 \pm 99
$$

$394 \pm 121$

0.0065

$$
(n=5)
$$

$$
827 \pm 240
$$

$$
1,357 \pm 305
$$

$<0.0001$

$$
(n=5)
$$

Note. $\mathrm{PaO}_{2} / \mathrm{FiO}_{2}$ is the ratio of oxygen in arterial blood to fraction of inspired oxygen. $\mathrm{PaO}_{2} / \mathrm{FiO}_{2} \geq 400 \mathrm{mmHg}$ is normal. ARM $+\mathrm{PEEP}$ returned the $\mathrm{PaO}_{2} / \mathrm{FiO}_{2}$ to awake levels at T3, T4, and T5. Awake EELV $(\mathrm{n}=6)$ was $1,387 \pm 581(P=0.0014)$. EELV returned to awake levels within 20 minutes of ARM + PEEP. CT scan showed higher percentage of normal lung aeration in the ARM + PEEP group. $P$ value $<0.05$ was considered significant. 


\section{Appendix C}

Table C-5

Outcome Data Collection

\begin{tabular}{|c|c|c|c|c|c|}
\hline \multicolumn{6}{|c|}{$\begin{array}{l}\text { Almarakbi, W., Fawzi, H., Alhashemi, J., (2009). Effects of four intraoperative ventilatory strategies on respiratory } \\
\text { compliance and gas exchange during laparoscopic gastric banding in obese patients. British Journal of Anesthesia, } 102 \text { (6), } \\
862-868 .\end{array}$} \\
\hline \multicolumn{6}{|c|}{$\begin{array}{rrrrr}\text { PEEP } & \text { ARM } & \text { ARM + PEEP } & \text { ARM Q 10 MIN } & P \text { value } \\
\mathrm{n}=15 & \mathrm{n}=15 & \mathrm{n}=15 & + \text { PEEP } & \mathrm{n}=15\end{array}$} \\
\hline $\begin{array}{l}\text { Lung Compliance } \\
\left(\mathrm{ml} \mathrm{cm} \mathrm{H} \mathrm{O}^{-1}\right)\end{array}$ & No Change & No Change & $\begin{array}{r}\text { Improved but } \\
\text { not sustained } \\
30-35\end{array}$ & $\begin{array}{r}\text { Improved } \\
40-45\end{array}$ & $<0.01$ \\
\hline $\begin{array}{l}\mathrm{PaO}_{2} \\
(\mathrm{kPa})\end{array}$ & No Change & No Change & $\begin{array}{l}\text { Improved but } \\
\text { not sustained }\end{array}$ & $\begin{array}{r}\text { Improved and } \\
\text { sustained at all } \\
\text { time intervals }\end{array}$ & $<0.01$ \\
\hline $\mathrm{PACU} \mathrm{SpO} 2$ & $92-93 \%$ & $92-93 \%$ & $94-95 \%$ & $96-97 \%$ & $<0.01$ \\
\hline
\end{tabular}

(\%)

Note. Compliance is the ability of the lung to stretch and expand. Low compliance indicates stiff lungs, while high compliance

indicates a pliable lung with low elastic recoil. Compliance is measured as $C=\frac{V T}{\text { Plateu pressure }- \text { PEEP }}$. The ARM every 10 minutes +

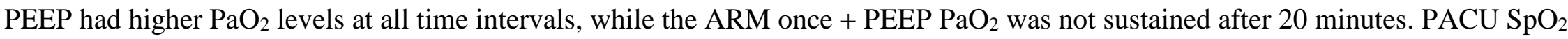
was highest in the ARM every 10 minutes + PEEP Statistical significance defined as $P<0.05$. 


\section{Appendix C}

Table C-6

Outcome Data Collection

Remistico, P., Araujo, S., Castilho de Figueiredu, L., Aquim, E., Gomes, L., Sombrio, M., Ambiel, S., (2011). Impact of alveolar recruitment maneuver in the postoperative period of videolaparoscopic bariatric surgery. Revista Brasileeira de Anestesiologia, 61 (2).

\begin{tabular}{|c|c|c|c|c|c|c|c|}
\hline \multirow[b]{2}{*}{$\begin{array}{l}\text { Spirometry Values } \\
\text { (mean } \pm \text { standard deviation) }\end{array}$} & \multirow[b]{2}{*}{$\underline{\text { Pre }}$} & \multicolumn{2}{|c|}{ Control Group } & \multicolumn{3}{|c|}{ ARM Group } & \multirow[t]{2}{*}{$P$ value } \\
\hline & & $\underline{\text { POD \#1 }}$ & $\underline{\text { POD \#2 }}$ & $\underline{\text { Pre }}$ & $\underline{\text { POD \#1 }}$ & $\underline{\text { POD \#2 }}$ & \\
\hline Forced Vital Capacity (FVC) & $3.5 \pm 0.6$ & $2.5 \pm 0.5$ & $2.4 \pm 0.7$ & $3.5 \pm 0.9$ & $2.6 \pm 1.0$ & $2.7 \pm 1.1$ & $\leq 0.001$ \\
\hline $\begin{array}{l}\text { Forced Expiratory Volume in } \\
1 \text { second }\left(\mathrm{FEV}_{1}\right)\end{array}$ & $3 \pm 0.6$ & $2.0 \pm 0.4$ & $2 \pm 0.5$ & $2.8 \pm 1$ & $2.2 \pm 1$ & $2.2 \pm 1$ & \\
\hline $\begin{array}{l}\text { Maximum Voluntary } \\
\text { Ventilation (MVV) }\end{array}$ & $108 \pm 28.7$ & $73 \pm 13.8$ & $75 \pm 22.2$ & $106 \pm 40$ & $83.4 \pm 40$ & $83.3 \pm 30.7$ & \\
\hline $\begin{array}{l}\text { Peak Expiratory Flow (PEF) } \\
\text { Forced Expiratory Flow (FEF } \\
\text { 25-75\%) } \\
\text { (mean } \pm \text { standard deviation) }\end{array}$ & $350 \pm 95.5$ & $228 \pm 63.1$ & $267.7 \pm 95.8$ & $346 \pm 175$ & $269 \pm 156$ & $289 \pm 166$ & \\
\hline $\begin{array}{l}\text { BORG Scale } \\
\text { (mean } \pm \text { standard deviation) }\end{array}$ & & $4.1 \pm 2.25$ & $2.87 \pm 1.92$ & & $5.6 \pm 2.41$ & $3.07 \pm 2.12$ & $<0.001$ \\
\hline $\begin{array}{l}\text { Post-op Chest Radiographs } \\
\text { Atelectasis } \\
\text { Pleural Effusion }\end{array}$ & & $\begin{array}{l}40 \% \\
20 \%\end{array}$ & & & $\begin{array}{c}0 \% \\
13 \%\end{array}$ & & $<0.02$ \\
\hline
\end{tabular}

Note. The BORGd scale in a subjective numerical scale where patients rate their perceived level of exertion. FVC- total volume forcibly exhaled. FVC - $_{1}$ volume exhaled in first second. MVV- maximum voluntary ventilation. $\mathrm{FEF}_{25-75 \%}$-the flow of air coming out of the lung during the middle portion of a forced expiration. Statistical significance was a $P \leq 0.05$. 


\section{Appendix D}

Table D-1

Critical Appraisal Skills Programme (CASP) Randomized Control Trials Checklist

Chalhoub, V., Yazigi, A., Sleilaty, G., Haddad, F., Noun, R., Madi-Jebra, S., \& Yazbeck, P., (2007). Effect of vital capacity manoeuvers on arterial oxygenation in morbidly obese patients undergoing open bariatric surgery. European Journal of Anesthesiology, 24, 283-288.

\section{A) Are the results of the trial valid?}

1. Did the trial address a clearly focused issue?

2. Was the assignment of patients to treatments randomized?

3. Were all of the patients who entered the trial properly accounted for at its conclusion?

4. Were patients, health workers and study personnel "blind" to treatment?

5. Were the groups similar at the start of the trial?

6. Aside from the experimental intervention, were the groups treated equally?

\section{B) What are the results?}

7. How large was the treatment effect?

8. How precise was the estimate of the treatment effect?

\section{C) Will the results help locally?}

9. Can the results be applied in your context?

(or to the local population?)

10. Were all clinically important outcomes considered?

11. Are the benefits worth the harms and costs?

YES
X
X
X

\section{CAN'T}

TELL

X

$\mathrm{X}$

$\mathrm{X}$

$\mathrm{X}$

$\mathrm{X}$

X

Treatment effect was not specifically mentioned.

Treatment effect was not specifically mentioned.

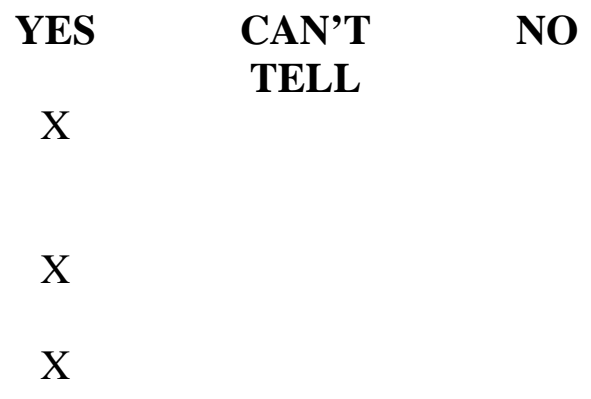
Note. Alveolar gas equation was utilized to determine $\mathrm{PAO}_{2}$. 


\section{Appendix D}

Table D-2

Critical Appraisal Skills Programme (CASP) Randomized Control Trials Checklist

Talab, H., Zabani, I., Abdelrahman, H., Bukhari, W., Mamoun, I., Ashour, M., Sadeq, B., \& Sayed, S. (2009). Intraoperative ventilatory strategies for the prevention of pulmonary atelectasis in obese patients undergoing laparoscopic bariatric surgery. Anesthesia \& Analgesia, 109, (5), 1511-1516

\begin{tabular}{|c|c|c|c|}
\hline A) Are the results of the trial valid? & YES & $\begin{array}{l}\text { CAN'T } \\
\text { TELL }\end{array}$ & NO \\
\hline $\begin{array}{l}\text { 1. Did the trial address a clearly focused } \\
\text { issue? }\end{array}$ & $\mathrm{X}$ & & \\
\hline $\begin{array}{l}\text { 2. Was the assignment of patients to } \\
\text { treatments randomized? }\end{array}$ & $\mathrm{X}$ & & \\
\hline $\begin{array}{l}\text { 3. Were all of the patients who entered the } \\
\text { trial properly accounted for at its } \\
\text { conclusion? }\end{array}$ & $\mathrm{X}$ & & \\
\hline $\begin{array}{l}\text { 4. Were patients, health workers and study } \\
\text { personnel "blind" to treatment? }\end{array}$ & $\mathrm{X}$ & & \\
\hline $\begin{array}{l}\text { 5. Were the groups similar at the start of } \\
\text { the trial? }\end{array}$ & $\mathrm{X}$ & & \\
\hline 6. Aside from the experimental & $\mathrm{X}$ & & \\
\hline
\end{tabular}
intervention, were the groups treated equally?

\section{B) What are the results?}

7. How large was the treatment effect?

Treatment effect was not specifically mentioned.

8. How precise was the estimate of the treatment effect?

Treatment effect was not specifically mentioned.

\section{C) Will the results help locally?}

YES

CAN'T

NO

9. Can the results be applied in your context?

(or to the local population?)

10. Were all clinically important outcomes TELL

$\mathrm{X}$

$\mathrm{X}$ considered?

11. Are the benefits worth the harms and

$\mathrm{X}$ costs? 


\section{Appendix D}

Table D-3

Critical Appraisal Skills Programme (CASP) Randomized Control Trials Checklist

Futier, E., Constanatin, JM., Pelosi, P., Chanques, G., Massone, A., Petit, A., Kwiatkowski, F., Bazin, JE., \& Jaber, S. (2011). Noninvasive ventilation and alveolar recruitment maneuvers improve respiratory function during and after intubation of morbidly obese patients. Anesthesiology, 114, (6), 1354-1363.

\begin{tabular}{|c|c|c|c|}
\hline A) Are the results of the trial valid? & YES & $\begin{array}{l}\text { CAN'T } \\
\text { TELL }\end{array}$ & NO \\
\hline $\begin{array}{l}\text { 1. Did the trial address a clearly focused } \\
\text { issue? }\end{array}$ & $\mathrm{X}$ & & \\
\hline $\begin{array}{l}\text { 2. Was the assignment of patients to } \\
\text { treatments randomized? }\end{array}$ & $\mathrm{X}$ & & \\
\hline $\begin{array}{l}\text { 3. Were all of the patients who entered the } \\
\text { trial properly accounted for at its } \\
\text { conclusion? }\end{array}$ & $\mathrm{X}$ & & \\
\hline $\begin{array}{l}\text { 4. Were patients, health workers and study } \\
\text { personnel "blind" to treatment? }\end{array}$ & & $X$ & \\
\hline $\begin{array}{l}\text { 5. Were the groups similar at the start of } \\
\text { the trial? }\end{array}$ & $\mathrm{X}$ & & \\
\hline 6. Aside from the experimental & $\mathrm{X}$ & & \\
\hline
\end{tabular}
intervention, were the groups treated equally?

B) What are the results?

7. How large was the treatment effect?

Treatment effect was not specifically mentioned.

8. How precise was the estimate of the treatment effect?

Treatment effect was not specifically mentioned.

\section{C) Will the results help locally?}

YES

CAN'T

NO

9. Can the results be applied in your context?

(or to the local population?)

10. Were all clinically important outcomes TELL

$\mathrm{X}$

$\mathrm{X}$ considered?

11. Are the benefits worth the harms and

$\mathrm{X}$ costs? 


\section{Appendix D}

Table D-4

Critical Appraisal Skills Programme (CASP) Randomized Control Trials Checklist

Reinius, H., Jonsson, L., Gustafsson, S., Sundbom, M., Duvernoy, O., Pelosi, P., Hedenstieerna, G., \& Freden, F. (2009). Prevention of atelectasis in morbidly obese patients during general anesthesia and paralysis. Anesthesiology, 111, (5), 979-987.

\begin{tabular}{|c|c|c|c|}
\hline A) Are the results of the trial valid? & YES & \multirow[t]{4}{*}{$\begin{array}{l}\text { CAN'T } \\
\text { TELL }\end{array}$} & \multirow[t]{4}{*}{ NO } \\
\hline $\begin{array}{l}\text { 1. Did the trial address a clearly focused } \\
\text { issue? }\end{array}$ & $\mathrm{X}$ & & \\
\hline $\begin{array}{l}\text { 2. Was the assignment of patients to } \\
\text { treatments randomized? }\end{array}$ & $\mathrm{X}$ & & \\
\hline $\begin{array}{l}\text { 3. Were all of the patients who entered the } \\
\text { trial properly accounted for at its } \\
\text { conclusion? }\end{array}$ & $\mathrm{X}$ & & \\
\hline $\begin{array}{l}\text { 4. Were patients, health workers and study } \\
\text { personnel "blind" to treatment? }\end{array}$ & & \multirow[t]{4}{*}{$\mathrm{X}$} & \\
\hline $\begin{array}{l}\text { 5. Were the groups similar at the start of } \\
\text { the trial? }\end{array}$ & $\mathrm{X}$ & & \\
\hline $\begin{array}{l}\text { 6. Aside from the experimental } \\
\text { intervention, were the groups treated } \\
\text { equally? }\end{array}$ & $\mathrm{X}$ & & \\
\hline \multicolumn{3}{|l|}{ B) What are the results? } & \\
\hline 7. How large was the treatment effect? & $\begin{array}{l}\text { Treatmen } \\
\text { mentione }\end{array}$ & was not $s$ & cally \\
\hline $\begin{array}{l}\text { 8. How precise was the estimate of the } \\
\text { treatment effect? }\end{array}$ & \multicolumn{3}{|c|}{$\begin{array}{l}\text { Treatment effect was not specifically } \\
\text { mentioned. }\end{array}$} \\
\hline C) Will the results help locally? & YES & \multirow[t]{4}{*}{$\begin{array}{l}\text { CAN'T } \\
\text { TELL }\end{array}$} & \multirow[t]{4}{*}{ NO } \\
\hline $\begin{array}{l}\text { 9. Can the results be applied in your } \\
\text { context? } \\
\text { (or to the local population?) }\end{array}$ & $\mathrm{X}$ & & \\
\hline $\begin{array}{l}\text { 10. Were all clinically important outcomes } \\
\text { considered? }\end{array}$ & $\mathrm{X}$ & & \\
\hline $\begin{array}{l}\text { 11. Are the benefits worth the harms and } \\
\text { costs? }\end{array}$ & $\mathrm{X}$ & & \\
\hline
\end{tabular}




\section{Appendix D}

Table D-5

Critical Appraisal Skills Programme (CASP) Randomized Control Trials Checklist

Almarakbi, W., Fawzi, H., Alhashemi, J., (2009). Effects of four intraoperative ventilatory strategies on respiratory compliance and gas exchange during laparoscopic gastric banding in obese patients. British Journal of Anesthesia, 102 (6), 862 - 868.

\begin{tabular}{lr}
\hline A) Are the results of the trial valid? & YES \\
$\begin{array}{l}\text { 1. Did the trial address a clearly focused } \\
\text { issue? }\end{array}$ & $\mathrm{X}$ \\
2. Was the assignment of patients to \\
treatments randomized? \\
$\begin{array}{l}\text { 3. Were all of the patients who entered the } \\
\text { trial properly accounted for at its } \\
\text { conclusion? }\end{array}$ \\
$\begin{array}{l}\text { 4. Were patients, health workers and study } \\
\text { personnel "blind" to treatment? }\end{array}$ \\
$\begin{array}{l}\text { 5. Were the groups similar at the start of } \\
\text { the trial? }\end{array}$ \\
$\begin{array}{l}\text { 6. Aside from the experimental } \\
\text { interventon, wer the groups treated }\end{array}$
\end{tabular}
intervention, were the groups treated equally?

B) What are the results?

7. How large was the treatment effect?

Treatment effect was not specifically mentioned.

8. How precise was the estimate of the treatment effect?

Treatment effect was not specifically mentioned.

\section{C) Will the results help locally?}

$\begin{array}{cc}\text { YES } & \text { CAN'T } \\ \text { TELL } & \text { NO } \\ X & \\ X & \\ X & \end{array}$

\section{TELL}

NO

\section{X}

X

$\mathrm{X}$

X

$\mathrm{X}$

$\mathrm{X}$

9. Can the results be applied in your context?

(or to the local population?)

10. Were all clinically important outcomes considered?

11. Are the benefits worth the harms and costs? 


\section{Appendix D}

Table D-6

Critical Appraisal Skills Programme (CASP) Randomized Control Trials Checklist

Remistico, P., Araujo, S., Castilho de Figueiredu, L., Aquim, E., Gomes, L., Sombrio, M., Ambiel, S., (2011). Impact of alveolar recruitment maneuver in the postoperative period of videolaparoscopic bariatric surgery. Revista Brasileeira de Anestesiologia, 61 (2).

\section{A) Are the results of the trial valid?}

1. Did the trial address a clearly focused issue?

2. Was the assignment of patients to treatments randomized?

3. Were all of the patients who entered the trial properly accounted for at its conclusion?

4. Were patients, health workers and study personnel "blind" to treatment?

5. Were the groups similar at the start of the trial?

6. Aside from the experimental intervention, were the groups treated equally?

\section{B) What are the results?}

7. How large was the treatment effect?

8. How precise was the estimate of the treatment effect?

\section{C) Will the results help locally?}

9. Can the results be applied in your context?

(or to the local population?)

10. Were all clinically important outcomes considered?

11. Are the benefits worth the harms and costs?

YES
$X$
$X$
$X$
$X$
$X$
$X$

Treatment effect was not specifically mentioned.

Treatment effect was not specifically mentioned.

\section{CAN'T \\ TELL}

NO

X

X

X

X

X

X

$\begin{array}{cc}\text { YES } & \text { CAN'T } \\ \text { TELL } & \text { NO } \\ X & \\ X & \\ X & \end{array}$




\section{Appendix E}

Cross Study Analysis Table

\begin{tabular}{|c|c|c|}
\hline Study & Protocol & Outcomes \\
\hline Study 1 & $\underline{\text { ABG Analysis }}$ & $\underline{\mathrm{SaO}}_{2}(\%)$ \\
\hline et al.,2007) & $\begin{array}{l}\text { T0: Before application of VCM and/or PEEP. } \\
\text { T1: } 5 \text { minutes after application of VCM and/or PEEP. }\end{array}$ & $\begin{array}{l}\text { Increased from } 97.5 \pm 1.7 \text { and } 98.5 \pm .9 \text { at } \mathrm{T} 1 \text { and } \mathrm{T} 2 \\
\text { in PEEP alone group to } 98.8 \pm .7 \text { and } 98.9 \pm .7 \text { at } \mathrm{T} 1 \\
\text { and } \mathrm{T} 2 \text { in } \mathrm{ARM}+\mathrm{PEEP} \text { group. }\end{array}$ \\
\hline & T2: Before abdominal closure. & $\underline{\mathrm{PaO}}_{2}(\mathrm{mmHg})$ \\
\hline
\end{tabular}

Increased from $110.0 \pm 35.3$ and $140.9 \pm 43.2$ at $\mathrm{T} 1$ and T2 in PEEP alone group to $170.6 \pm 46.6$ and $182.0 \pm 32.4$ in ARM + PEEP group.

\section{$\underline{\mathrm{A}-\mathrm{a} \mathrm{DO}} 2(\mathrm{mmHg})$}

Decreased from $134.1 \pm 36.5$ and $104.9 \pm 41.9$ at $\mathrm{T} 1$ and T2 in PEEP alone group to $77.4 \pm 48.3$ and $65.4 \pm$ 32.5 at $\mathrm{T} 1$ and $\mathrm{T} 2$ in the ARM + PEEP group.

\section{Study 2}

(Talab et

al., 2009)

\section{$\underline{\mathrm{A}-\mathrm{a} \mathrm{DO}} 2(\mathrm{mmHg})$}

Decreased postoperative A-a $\mathrm{O}_{2}$ gradient of $29.85 \pm$ 18.83 in the VCM at $40 \mathrm{~cm} \mathrm{H}_{2} \mathrm{O}+$ PEEP $10 \mathrm{~cm} \mathrm{H}_{2} \mathrm{O}$ compared to $53.05 \pm 30.42$ in the VCM of $40 \mathrm{~cm} \mathrm{H}_{2} \mathrm{O}$ + PEEP of $5 \mathrm{~cm} \mathrm{H}_{2} 0$ and $63.23 \pm 35.12$ in the VCM + PEEP group.

\section{CT Imaging}

\section{CT Imaging}


Completed on admission to the hospital and immediately following PACU discharge.
Greater percentage of overall lung atelectasis seen in the VCM + PEEP $5 \mathrm{~cm} \mathrm{H}_{2} \mathrm{O}$ and VCM + ZEEP groups compared the VCM of $40 \mathrm{~cm} \mathrm{H}_{2} \mathrm{O}+$ PEEP of $10 \mathrm{~cm} \mathrm{H}_{2} 0$ group. $10 \%$ of participants had no atelectasis on CT in the VCM of $40 \mathrm{~cm} \mathrm{H}_{2} \mathrm{O}+$ PEEP of $10 \mathrm{~cm} \mathrm{H} \mathrm{H}_{2} \mathrm{O}$, while $0 \%$ showed normal lung aeration in the other groups.

\section{Need for $100 \% \mathrm{O}_{2}$ in PACU (\%)}

Decreased need for $100 \% \mathrm{O}_{2}$ in the PACU to $4.5 \%$ in the VCM of $40 \mathrm{~cm} \mathrm{H} \mathrm{H}_{2} \mathrm{O}$ PEEP of $10 \mathrm{~cm} \mathrm{H}_{2} 0$ group compared $16.7 \%$ and $26.3 \%$ in the VCM of $40 \mathrm{~cm}$ $\mathrm{H}_{2} \mathrm{O}+$ PEEP of $5 \mathrm{~cm} \mathrm{H}_{2} \mathrm{O}$ and VCM + PEEP groups respectively.

\section{$\underline{\text { PACU LOS (min) }}$}

VCM of $40 \mathrm{~cm} \mathrm{H}_{2} \mathrm{O}+$ PEEP $10 \mathrm{~cm} \mathrm{H}_{2} 0$ had decreased length of stay in PACU $66.9 \pm 18.6$ compared to 77.5 \pm 20.35 in VCM of $40 \mathrm{~cm} \mathrm{H}_{2} 0+$ PEEP of $5 \mathrm{~cm} \mathrm{H}_{2} 0$ and $87.5 \pm 35.31$ in VCM + ZEEP group.

\section{Pulmonary Complications}

4 pulmonary complications in the VCM + ZEEP group. 3 pulmonary complications in the VCM of 40 $\mathrm{cm} \mathrm{H}_{2} \mathrm{O}+$ PEEP of $5 \mathrm{~cm} \mathrm{H}_{2} \mathrm{O} .0$ pulmonary

complications in the VCM of $40 \mathrm{~cm} \mathrm{H}_{2} \mathrm{O}+$ PEEP of $10 \mathrm{~cm} \mathrm{H}_{2} \mathrm{O}$. 
Study 3

(Futier et

al., 2011) T:0 prior to preoxygenation.

T:1 5 minutes after preoxygenation.

T2: immediately after intubation.

T3: Immediately after ETI.

T4: 5 min after the onset of mechanical ventilation.

\section{$\underline{\text { EELV }}$}

EELV measurements obtained via helium dilution method in awake patients. Subsequent EELV after ETI and 5 minutes after mechanical ventilation. EELV obtained from ventilator automatically.

\section{Study 4}

(Reinus et

al., 2009)

$\underline{\text { ABG Analysis }}$

T0: Awake.

T1: 5 minutes after induction and intubation.

\section{$\underline{\mathrm{PaO}_{2}(\mathrm{mmHg})}$}

$\mathrm{PaO}_{2} 375 \pm 82$ in the NPPV $+\mathrm{ARM}$ group at $\mathrm{T} 4$ compared to

$128 \pm 54$ and $93 \pm 25$ in the NPPV group and Conventional group respectively.

\section{$\underline{\operatorname{EELV}(\mathrm{mL} / \mathrm{kg} \mathrm{PBW})}$}

Increase of EELV to $40 \mathrm{~mL} / \mathrm{kg}$ in NPPV + ARM group compared to $35 \mathrm{~mL} / \mathrm{kg}$ and $20 \mathrm{~mL} / \mathrm{kg}$ in the NPPV group alone and Conventional group respectively.

\section{$\underline{\mathrm{PaO} 2 / \mathrm{FiO} 2(\mathrm{mmHg})}$}

Increase in $\mathrm{PaO} 2 / \mathrm{FiO} 2$ ratio to near awake levels in the ARM + PEEP of $10 \mathrm{~cm} \mathrm{H}_{2} 0$ at T2: $419 \pm 106$, T3: $412 \pm 99$, and T4: $394 \pm 121$. PaO2/FiO2 ratio for PEEP alone group T2: $267 \pm$ 94, T3: $253 \pm$ 87, and T4 
T2: 5 minutes after intervention.

T3: 20 minutes after intervention.

T4: 40 minutes after intubation.

\section{CT Imaging}

T0: Awake.

T1: 5 minutes after induction and intubation.

T2: 5 minutes after intervention.

T3: 20 minutes after intervention.

Study 5

(Almarakbi

et al.,

2009)

\section{ABG Analysis}

T0: 5 minutes after induction and intubation.

T10: 10 minutes after pneumoperitoneum formation prior ARM.

T20: 10 minutes, immediately following ARM.

T30: 10 minutes, immediately following ARM.
$262 \pm 88 . \mathrm{PaO} 2 / \mathrm{FiO} 2$ ratio for $\mathrm{ARM}+\mathrm{ZEEP}$ group T2: $252 \pm 86$, T3: $225 \pm 82$, and T4: $217+83$.

\section{$\underline{\operatorname{EELV}(\mathrm{ml})}$}

EELV returned to near awake levels in the ARM + PEEP of $10 \mathrm{~cm} \mathrm{H}_{2} 0$ by T3: 1,357 \pm 305 compared to $1,085 \pm 304$ at T3 in the PEEP alone group and $805 \pm$ 215 at T3 in the ARM + ZEEP group.

CT Scan

(Total Lung \%)

Greater percentage of normal lung aeration in the $\mathrm{ARM}+\mathrm{PEEP}$ of $10 \mathrm{~cm} \mathrm{H}_{2} 0$ of $72 \pm 9$ compared to 64 \pm 11 in the PEEP alone group and $50 \pm 15$ in the ARM + ZEEP group.

\section{$\underline{\mathrm{PaO}} 2(\mathrm{kPa})$}

Improved $\mathrm{PaO}_{2}$ by T20 in the ARM (Q 10 minutes) + PEEP $10 \mathrm{~cm} \mathrm{H}_{2} \mathrm{O}$ to pre-induction levels that were sustained at T30, T40, and T50, compared the ARM (once) + PEEP $10 \mathrm{~cm} \mathrm{H} 0$ where $\mathrm{PaO}_{2}$ was only increased at T20. $\mathrm{PaO}_{2}$ in the PEEP alone and ARM alone groups never returned to pre-induction levels.

Lung Compliance $\left(\mathrm{ml} \mathrm{cm} \mathrm{H}_{2} \mathrm{O}^{-1}\right)$ 
T40: 10 minutes, immediately following ARM.

T50: 10 minutes, immediately following ARM.

\section{Lung Compliance}

Automatically calculated on a breath-by-breath basis by the anesthesia machine.

\section{$\underline{\text { PACU SpO2 }}$}

Recorded every 10 minutes for a total of 1 hour.
Lung compliance improved in the ARM (Q 10 minutes) + PEEP $10 \mathrm{~cm} \mathrm{H}_{2} \mathrm{O}$ to $40-45$ by $\mathrm{T} 20$ and remained elevated at T30, T40, and T50. Lung compliance improved to 30-35 in the ARM (once) + PEEP $10 \mathrm{~cm} \mathrm{H}_{2} \mathrm{O}$ at T20 but was not sustained at any other time interval. Lung compliance remained decreased in the PEEP alone and ARM alone groups, never returning to pre-pneumoperitoneum levels.

\section{$\underline{\mathrm{PACU} \mathrm{SpO}_{2}} \underline{(\%)}$}

PACU $\mathrm{SpO}_{2}$ was highest in the ARM (Q 10 minutes) + PEEP $10 \mathrm{~cm} \mathrm{H}_{2} \mathrm{O}$ at 96-97, while PEEP alone group had an $\mathrm{SpO}_{2}$ of 92-93, ARM alone group had an $\mathrm{SpO}_{2}$ of 92-93, and the ARM (once) + PEEP $10 \mathrm{~cm} \mathrm{H}_{2} 0$ group had an $\mathrm{SpO}_{2}$ of 94-95. 
Study 6

(Remistico

et al.,

2011)

\section{BORG Scale}

Completed on POD 1 and POD 2.

\section{$\underline{\text { Chest Radiographs }}$}

Completed preoperatively and postoperatively
Although pre-procedure spirometry values decreased for all patients in both the Control and ARM group, FVC, FEV 1 , MVV, PEF, FEF $25-75 \%$ were all improved in the ARM group compared to the control group on postop day 1 and postop day 2 .

\section{BORG Scale}

The ARM group showed a statistically significant improvement in BORG scores from first to second postoperative day. POD 1- $5.6 \pm 2.41$, POD 2-3.07 \pm 2.12

\section{Chest Radiographs}

Postoperative chest radiographs demonstrated that 40 $\%$ of participants had atelectasis and $20 \%$ had a pleural effusion in the Control group. In the ARM group $0 \%$ of participants had evidence of atelectasis and only $13 \%$ had evidence of pleural effusion via chest radiograph. 